\title{
A New Model for Enhancing Student Portal Usage in Saudi Arabia Universities
}

\author{
Salem Suliman T. Alatawi \\ School of Computing \\ Universiti Teknologi Malaysia \\ Johor, Malaysia \\ salem.net1@hotmail.com
}

\author{
Suraya Miskon \\ Azman Hashim International Business \\ School, Universiti Teknologi Malaysia \\ Johor, Malaysia \\ suraya@utm.my
}

\author{
Norris Syed Abdullah \\ Azman Hashim International Business \\ School, Universiti Teknologi Malaysia \\ Johor, Malaysia \\ norris@utm.my
}

\author{
Fahad Ghabban \\ College of Computer Science and Engineering \\ Taibah University \\ Medina, Saudi Arabia \\ fghaban@taibahu.edu.sa \\ Ibrahim Alfadli \\ College of Computer Science and Engineering \\ Taibah University \\ Medina, Saudi Arabia \\ ialfadli@taibahu.edu.sa
}

\author{
Faisal Saeed \\ College of Computer Science and Engineering \\ Taibah University \\ Medina, Saudi Arabia \\ fsaeed@taibahu.edu.sa \\ Omair Ameerbakhsh \\ College of Computer Science and Engineering \\ Taibah University \\ Medina, Saudi Arabia \\ oameerbakhsh@taibahu.edu.sa
}

\begin{abstract}
Portals are gateways that provide users with the information they need from different sources and display it on a single page. It is important to see that universities utilize the resources and services provided by their student portals. With the rapid development of Information and Communication Technology (ICT), the Ministry of Education in Saudi Arabia aims to develop and improve student portals by providing highquality teaching services through the university portal systems. This paper discusses the importance of student portal usage in Saudi Arabian universities and investigates the factors that influence the utilization of student portals as perceived by the students of the Saudi universities. Based on these factors, a model is proposed which identifies students' expectations about the Saudi university portals. A quantitative methodology was employed to develop the model. The results revealed that 8 out of 10 factors of the model are significant and positively affect student portal usage. The enhancement of student portals based on the identified significant factors will assist the universities to increase their utilization and their provided services.
\end{abstract}

Keywords-university portal; higher education; e-services; elearning; quality of service; utilization of student portals; ICT

\section{INTRODUCTION}

High-quality web portals are critical to commercial and non-commercial organizations $[1,2]$. A portal is defined as a general knowledge management system that helps companies to share, reuse, create or exchange information [3]. A university portal provides its users a specialized view that matches their needs and meets their software and hardware requirements. To build a university portal that is updated regularly with the latest information and can accommodate additional services is a significant challenge [4]. The main concern is to build a portal that controls, coordinates, interacts and takes feedbacks from customers (visitors, staff and students). The Ministry of Higher Education in Saudi Arabia works close with Saudi universities to improve the quality of higher education in order to ensure that university graduates have skills and learning outcomes in line with the international standards and job market requirements. Despite the good Information and Communication Technology (ICT) infrastructure in Saudi universities, the usage of university student portals remains low [5]. According to [6], a big challenge that Saudi universities face is the lack of awareness regarding the use of ICT among students, faculty members, and administrative staff. Many universities in Saudi Arabia spend generously on ICT, but this expenditure does not lead to significant improvements in the usage of ICT services. Many universities have adequate ICT infrastructure, but they do not use it effectively [7]. Higher education institutions, particularly universities in developed countries, are heavily involved in portals which have become an essential tool for service delivery and communication between faculty members, administrative staff, and, most important, students [8].

Several studies have been conducted in Saudi Arabia on the importance and usage of university student portals. Authors in [9] showed that the official university portal for King AbdulAziz University is well-below the expected standard. The study 
claims that King Abdul-Aziz University's portal does not match the standards of design, content, user support, and navigation and the undergraduate students are dissatisfied with it [10]. The aim of [10] was to explore usability problems within Saudi university websites in comparison with the UK university websites by applying the SUS methods and Thinking aloud method to measure the usability of the websites. The results illustrated that Saudi students faced various usability problems related with satisfaction, integration, and confidence. The author in [2] evaluated the EduGate, an online academic portal of King Saud University and problems were found concerning its design and content. These problems reduced the usage of the portal and dissatisfied academic staff. The author in [11] revealed that Saudi university portals need to focus on their content to meet the needs of staff and students and to increase their level of usage. Furthermore, authors in [12] revealed that the score for using King Khalid University's website is 53.5 while the average industry score of using a website is 65 . This indicates that there are problems impeding the effectiveness and efficiency of the university portal resulting in minimal usage.

Given the above background, this study investigates the factors that affect students' usage of their university portal by proposing a model that meets student expectations and increases their satisfaction. This model will help the universities to communicate more efficiently with their students.

\section{RELATED WORK}

Web portals are general knowledge management systems that help institutions to share, reuse, create, or exchange information or knowledge [3]. Portals have been employed increasingly to manage the communication between different stakeholders in an organization or initiative. Educational web portals have become more responsive and turned out to be very dynamically based on the demands and the requirements of the varying academic community. The communication between teachers and students is often conducted through these websites and even more these days due to the Covid 19 pandemic. These portals actually integrate the application, content, and information together in order to help the end users. University student portals provide customers with a specialized view that matches their needs and meets their software and hardware requirements. The understanding of the users' needs is a key element in the student portal usage. It mainly includes four important things, namely the accessibility standards, page layout, graphic design, and, most important, content design [13]. Therefore, the main concern of the university is to build a portal that is able to control, coordinate, and receive feedback from the users (visitors, staff, and students). Such input contributes to developing a portal that will meet the expectations of end-users and the industry standards $[2,13]$.

King Saud University and King Abdul-Aziz University are among the top five universities of Saudi Arabia [14, 15]. Authors in [14] indicated that information technology infrastructure is a key success factor that increases students' confidence in using Saudi university portals. As such, the author in [15] recommended updating the information of the portals, e-services, and redesigning in order to increase their use. He examined the attitudes of faculty members towards the use of virtual learning portals in teaching language programs at major Saudi universities. Authors in [16] evaluated and compared the awareness and the level of the use of portals among the students of the Al-Jouf University. The study concluded that the undergraduate students of the University lack the necessary information skills needed to meet their academic and research requirements in order to continue to use the portal. Authors in [17] examined different factors that affect the use of the university portals and determined the level of the use of e-learning portals in Saudi Arabia while they compared the results with the results from studies conducted in other countries. It was revealed that the technical infrastructure of the portal, instructor knowledge of the use of portal technologies, and student knowledge of using computer systems are important to the success and increase of the usage of the portal. The author in [18] conducted a comprehensive literature study to identify the current state of using the health information systems' portals in Saudi Arabia. The findings revealed that factors such as: design, privacy, and efficiency affect portal usage. Author in [19] examined the current situation of King Abdulaziz University portal content and proposed a content strategy, which can help the university to solve portal content issues and encourage users to use it. Also, this study recommended examining the students' perceptions regarding the use of the portal. The author in [20] examined the level of the use of academic portals by the staff of Alqassim University in Saudi Arabia. The results showed that the academic staff members lack awareness about the use of the available services in the portal. This study revealed that there is a need to increase the level of usage by training the academic members on how to use the services of the portal. Authors in [21] examined the level of use of university portals by identifying the factors that influence lecturers to use it. The result revealed that there are some issues such as: navigation, response time, minimum download time, and portal accessibility. This study recommended university decision makers and web designers to take into consideration these issues in order to increase the level of portal's usage. The author in [22] examined students' attitudes towards using electronic information resources of the library portal at Princess Nora University in Saudi Arabia. The results revealed that the management should attempt to decrease the gap between student attitudes and their use in order to increase the portal usage. In addition, authors in [10] examined the level of usage of the portal of the King AbdulAziz University among undergraduate students. It was found that students were dissatisfied with the portal. The study recommended the improvement of the level of the portal usage by solving the problems the students face.

In spite of the advancements being made in the domain of mobile portals in Saudi Arabia, there are aspects that present obstacles in the progress. For instance, authors in [23] ascertained several limitations related to mobile learning in Saudi Arabia, limitations related to processing performance, memory size, battery life, user interface, and the existence of various platforms. Other concerns encompass the availability of dependable and inexpensive web access from home, because the IT security in Saudi universities makes it difficult for students who are away from campus to access the university 
systems. The author in [24] highlighted the substandard wireless network and technical concerns. Utilizing mobile phones for education would render likely issues regarding the hardware specifications of the devices involved: small screen sizes, inadequate input options, small battery life, inadequate memory capacity, and inadequate video quality [26, 27].

Based on these limitations, this study focuses on student web portals in Saudi Arabia universities. Social Cognitive Theory (SCT), which is regarded as a very powerful theory related to human behavior, was utilized. The SCT was applied for investigating computer utilization in [28, 29]. The nature of the proposed model along with its theory allowed its extension to the acceptance and usage of web portals. The SCT was regarded as the base model because: first, the constructs that were used in the model represented the variables that were analyzed as the factors responsible for improving the web portals. Second, since the SCT was a relatively less-represented model in the adoption of the web portals, it was important to investigate its performance and application in the existing context. Finally, this model included all the appropriate and vital constructs that helped in understanding the behavior of an individual. According to [25], user behavior is an important key to enhance and continue using a website. In addition, user behavior and perceived enjoyment on websites are important factors regarding the increase of its usage [26]. Also, the consideration of user behavior provides useful guidelines for designers to deliver the optimum website design. According to [32], student behavior is the most important key factor to improve the use of an educational portal. Therefore, understanding students' expectations has significant influence on their performance and increases user satisfaction [33, 34].

Based on the previous studies, it was found that there are issues regarding the usage of portals of Saudi Arabia universities. These issues decrease the student portals usage and make the students dissatisfied with them. Therefore, this study will investigate the factors that prevent the undergraduate students from using the university student portals.

\section{MATERIALS AND METHODS}

\section{A. Population and Study Context}

This study uses the quantitative approach to achieve its objectives by investigating the importance of student portals and the most important factors that affect students to use the portals of Saudi universities. The collected data were from 399 participants and were gathered from students of four different universities, namely the University of Tabuk, Taibah University, Taif University, and King Faisal University, which are located in different states of Saudi Arabia. Also, the study used the PLS algorithm in SmartPLS3 to analyze the collected data.

\section{B. Factor Selection Method}

Five databases were used, namely ScienceDirect, Taylor \& Francis, Springer, Emerald, and Google Scholar to determine the importance of student portals and the most important factors which affect the students' usage. Moreover, this study attempts to investigate the importance of student portals among students based on their attitude in order to increase their performance. There are works indicating the importance of studying personal and organizational factors to enhance users' performance. The factors that enhance academic staff in Nigeria to use ITC in the library were examined in [59]. The findings of the study revealed that organization factors are the most important. Organization factors include the lack of ICT strategy and the lack of commitment by the institutional management. According to [60], personal and behavioral factors are key success factors in improving the performance of employees. It is essential to examine the impact of personal, behavioral, and organizational factors on the academic staff in universities in order to improve the performance of research productivity [61]. Personal factors, such as the level of skills for using ICT, are important. Therefore, this study identified the factors that affect students' use of the university portals by using Microsoft Excel to extract and filter the factors from previous studies. This approach consisted of four steps namely, search for suitable factors, filtering factors, naming three classification categories, and classifying the factors into these categories.

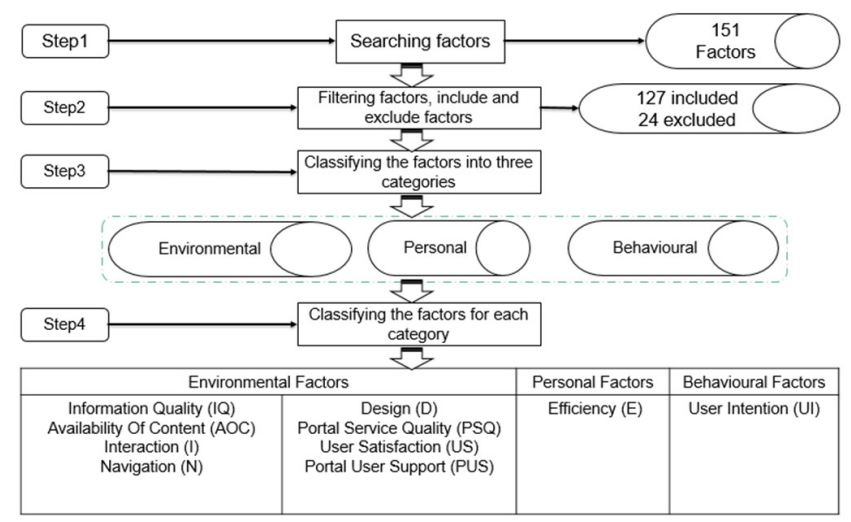

Fig. 1. Factor derivation process.

Firstly, 54 papers were reviewed. Twenty eight papers were found that were related to this study domain. From these included papers, 151 factors were identified. In the second step, the researchers filtered all identified factors to determine the included and excluded factors. In this step, the researchers identified 127 included sub-factors and excluded 24 factors. At the third step, the researchers extracted and classified the identified 127 sub- factors and factors into 3 categories, namely environmental, personal, and behavioral. Then, the researchers divided each category's sub-factors into the main factor. In the fourth step, the researchers identified the main factors related to each category. Regarding the environmental category, the researchers found that there are 8 main factors related with it. These factors are: Information Quality (IQ), Availability Of Content (AOC), Interaction (I), Navigation (N), Design (D), Portal Service Quality (PSQ), User Satisfaction (US), and Portal User Support (PUS). The personal category consists of 1 main factor namely Efficiency (E), and the behavioral category also consists of 1 main factor namely User Intention (UI), as shown in Figure 1. 


\section{1) Environmental Factors}

Environmental factors refer to the degree an individual trusts the technical and organizational infrastructure that should exist and the level of support for using the system [27] or the availability of technological and external resources of the organization such as money, time, and effort needed to ease the performance of a specific behavior.

\section{a) User Satisfaction}

In information technology, user satisfaction of web portals has been studied extensively. Authors in $[28,36]$ studied the direct influence of competing resources, user satisfaction, and the voluntariness on the portal usage. It has been used as a surrogate measure for the effectiveness of information systems [29]. User satisfaction is defined as the degree of successful interaction between users and the information system [30]. Authors in [31] described satisfaction as the degree of the comparison of the expectations with the perceived performance. The first hypothesis regarding user satisfaction is:

- Ha1: US positively affects students' use of the student portal.

\section{b) Information Quality}

Information quality is the quality of the information system output that reflects user needs such as accuracy, content, format and timing [33], which is critical to user acceptance [33]. IQ can predict consumer satisfaction [34]. Accordingly, providing a high-quality student portal will help provide innovative services to students. The assumption made regarding information quality is:

- Ha2: IQ positively affects students' use of the student portal.

\section{c) Interaction}

According to [35], interaction refers to the ease by which users can interact with the input and output of the system and their ability to learn through it. Human-computer interaction is vital to improving user performance [36]. Better humancomputer interaction provides good learning systems to create portals that are easy to use and increases user satisfaction [35]. As such, interaction helps improving student portal usage.

- Ha3: Interaction positively affects students' use of the student portal.

\section{d) Availability Of Content}

AOC can affect students' usage of the university portal [37]. Educational and non-educational services provided in the portal, such as online library services, email services, lecturer evaluation, and registration services are the key areas. The student portal should facilitate the accessibility to all services and be flexible, quick, and allow users to perform their tasks efficiently [38]. The students will be more satisfied when they get more available content.

- Ha4: AOC positively affects students' use of the student portal.

\section{e) Portal Service Quality}

Authors in [39] defined PSQ as the support from the information technology department concerning the user system. PSQ is also defined as the level of customers' expectations with the degree of the services delivered via the user information system [40]. According to [41], PSQ can be determined within the context of e-services as a portal that is responsive, available, accessible, and flexible. Therefore, PSQ is a key determinant of use and user satisfaction about the eservices provided in a portal [42].

- Ha5: PSQ positively affects students' use of the student portal.

\section{f) Design}

Portal design is considered an important factor that determines the usage of any online portal [43]. Portals through simple user interface design provide services and information that users need [44]. So, a student portal should include design features that help students enjoy their visit, which will lead to increased activity $[45,46]$.

- Ha6: Design positively affects students' use of the student portal.

\section{g) Navigation}

Navigation is a significant factor in using web portals [47]. Users should be able to move through portal links without getting lost. The ease of navigation is a critical component of portal usage [48]. Therefore, the definition of navigation refers to the ease of finding what the user wants in the portal [49]. The navigation hyperlinks should be available and must work properly [50].

- Ha7: Navigation positively affects students' use of the student portal.

\section{h) User Support}

US is the ability of the IT department to provide users with assistance when needed [51]. Moreover, because an academic portal is usually complex and needs qualified staff, it is necessary to have online US tools such as online chatting services provided via an instant messenger to help users resolve problems should they arise [28].

- Ha8: US positively affects students' use of the student portal.

Figure 2 presents the environmental factors which affect the students' use of a portal.

\section{2) Personal Factors}

This study suggests that the personal factors have a significant impact on the students' use of the portal. Moreover, personal factor efficiency refers to the judgements of people on their capabilities to organize and implement the required courses of action to achieve the required action [52].

\section{a) Efficiency}

A student portal is a good learning environment that helps students increase their abilities to learn [38]. Efficiency is a kind of self-evaluation that can assist the understanding of human behavior and its performance in specified tasks [53]. Even though student portals offer good information, their 
efficiency will decrease if the students' ability does not meet the expectations [54]. The students' ability to use the portal is vital for them to achieve their needs, as shown in Figure 3.

- Hb1: Efficiency positively affects students with using the students' portal.

\section{3) Behavioral Factors}

Authors in [55] defined UI as the degree by which a person can formulate clear plans to perform a determined future behaviour (Figure 4).

\section{a) User Intention}

UI is defined by the individual's behavioral intention and, in turn, the behavioral intentions are a function of an individual's attitude to the behavior. This is suggested by the Theory of Reasoned Action (TRA). The attitude towards a type of behavior is defined by a person's feelings toward that action and can be negative or positive [56]. Authors in [57] stated that behavioral intention is an important independent variable that predicts the actual use. Similarly, authors in [58] stated that behavioral intention is likely to be linked with the actual usage.

- Hc1: UI positively affects user with using the students' portal.

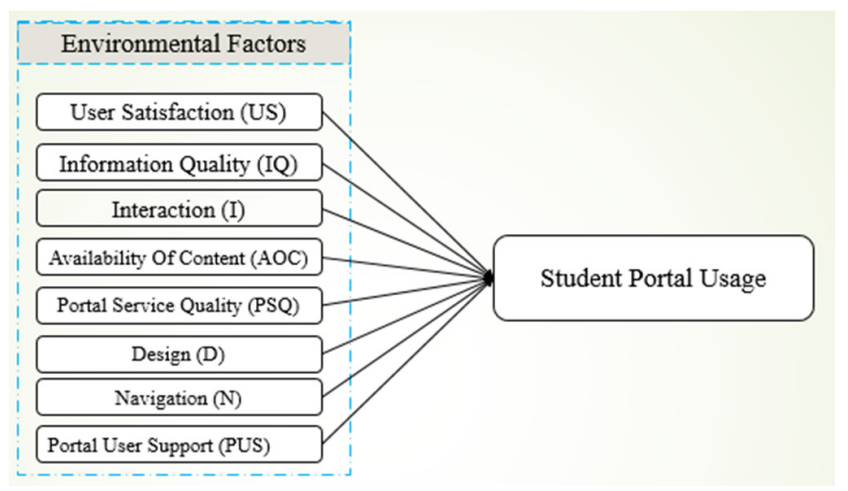

Fig. 2. Environmental factors.

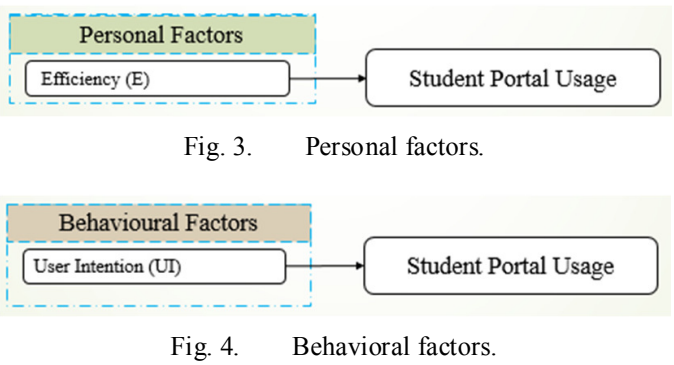

\section{Survey Instruments}

In this study, a questionnaire-based survey method was adopted and used to collect study data and test the hypotheses. The method includes data collection, data analysis, and report writing. Authors in [62] identified the questionnaire as recording the respondents' opinions on specific topic as a preformulated set of questions. Using a questionnaire method is efficient, less expensive, and less time-consuming compared to other methods such as interviews and observation. The goal of the developed data collection survey instruments was to measure the validity and reliability of each factor in the model. According to [63], the developing of data collection survey instruments includes three steps: defining the constructs and content domain, generating and judging measurement items, and constructing studies to develop and refine the scale. The first step in data collection is to define each construct definition in the model. The importance in a theory to identify the construct definition and its domain was also highlighted, and conducting a comprehensive literature review to determine them was recommended. Therefore, the authors of this study did a thorough literature review and defined each construct in the model based on the content domain of the study. The second step of generating and judging measurement items follows. In addition, using the existing literature is considered a good scientific method to determine the items of the study [63]. Therefore, the authors of the current paper identified the items from previous studies that are related to this domain.

\section{Face and Content Validity Assessment}

In this step, the researchers measured the face and content validity of the measurement items [64]. According to [65], via referring to the literature or an expert, content and face validity can be achieved. A content and face validity form to test the validity of the selected measurement items was developed based on the validity form in [66]. The validity form consists of the research title, a short description of the research, the goal of this form, construct definitions, and items choice type. The items include three types of choice, Perfect Match (maintain items as it is), Moderate Match (maintain item but some refining is needed), and Poor Match (remove item) as shown in Appendix C. The researchers distributed the validation form to 9 experts as shown in Table I. The researchers invited experts from different disciplines to examine whether the items of each construct represent the construct's definition. Some items were changed and deleted based on the experts' comments and feedback.

TABLE I. EXPERTS' PROFILES

\begin{tabular}{|c|c|c|}
\hline University & Department/School & Area of Expertise \\
\hline $\begin{array}{c}\text { Universiti Teknologi } \\
\text { Malaysia }\end{array}$ & School of Computing & $\begin{array}{c}1 \text { expert in Information systems, e- } \\
\text { commerce, m-commerce. }\end{array}$ \\
\hline $\begin{array}{c}\text { Universiti Teknologi } \\
\text { Malaysia }\end{array}$ & $\begin{array}{c}\text { Azman Hashim } \\
\text { International Business } \\
\text { School }\end{array}$ & $\begin{array}{c}1 \text { expert in Information systems, IT } \\
\text { project management, information } \\
\text { system planning. }\end{array}$ \\
\hline Taibah University & Community College & $\begin{array}{c}\text { experts in information systems } \\
\text { and computer science. }\end{array}$ \\
\hline Taibah University & $\begin{array}{c}\text { Faculty of Computer } \\
\text { Science and } \\
\text { Information Systems }\end{array}$ & $\begin{array}{c}5 \text { experts in information system } \\
\text { and computer science, educational } \\
\text { technology, e-learning. }\end{array}$ \\
\hline
\end{tabular}

\section{E. Data Analysis Tools}

To analyze the data, Partial Least Square (PLS) technique of Structural Equation Modeling (SEM) was used. By applying PLS-SEM, we were able to examine the measurement and the structural process of the proposed model. PLS-SEM is considered as a data analysis tool that validates predictive models [73]. SmartPLS software tool is appropriate for small sizes of data [73]. In this study, a two-type assessment to 
analyze the data has been applied by using SmartPLS V.3. The first assessment is the measurement model, which is accomplished by the assessment of indicator reliability, internal consistency, convergent validity, and discriminate validity. The second assessment is the structural model, which is used to assess path analysis hypotheses testing by examining the size and significance of the path coefficient and coefficient determination [73].

\section{RESULTS AND DISCUSSION}

This study examines the importance of student portal usage in Saudi universities by examining the most important factors affecting students' use of these portals. Ten factors were identified, 8 of which with a positive impact on students' usage of the student portal while the other 2 factors had no effect. These factors were divided into 3 main categories, namely environmental, personal, and behavioral. These 3 categories have three primary hypotheses. Furthermore, each primary hypothesis includes a sub-hypothesis depending on how many factors belong to each category in order to investigate the relationship between the constructs.

\section{A. Demographic Background}

As mentioned above, the study was conducted in 4 universities, in different states of Saudi Arabia. The total number of participants was 399. The distribution of the participants' gender indicates that the highest percentage of participants were female $(n=295,73 \%)$, while males were $\mathrm{n}=104,26.1 \%$. Regarding the participants' age distribution, 299 participants $(75 \%)$ were aged between 18 and 24 years, 50 participants $(12.5 \%)$ were in the range of 25 and 29 years, and the same number and percentage were more than 30 years old (50 participants, $12.5 \%$ ). The distribution of participants in the selected universities is: University of Tabuk $n=77,19.3 \%$, Taibah University $\mathrm{n}=131,32.8 \%$, Taif University $\mathrm{n}=91,22.8 \%$, and King Faisal University $\mathrm{n}=100,25.1 \%$. As for the participants' experience in using computer and internet, 51 participants $(13 \%)$ had less than 1 year of experience, 57 participants $14.2 \%$ had 1 to 3 years, 67 participants $16.7 \%$ had 3 to 5 years, 103 participants $25.8 \%$ had 5 to 10 years, and 121 participants $30.3 \%$ had more than 10 years of experience. Two hundred and thirty (27.6\%) participants had good computer skills, 154 participants had excellent computer skills (38.6\%), and 15 had low computer skills (3.8\%). Most (218) participants had excellent internet skills (54.6\%), 171 had good internet skills (42.9\%), and 10 had low internet skills (2.5\%).

\section{B. Data Analysis}

This study used the PLS algorithm in SmartPLS3 to identify the reliability and validity of the study items. Measurement and structural models were used to measure the study model and hypotheses. The measurement model examines the constructs and their items. It also determines the degree to which the indicators measure the construct. The structural model evaluated the reliability and validity of the measurement model, determined the measurement of each item and concluded that all are reflective items. Authors in [67] summarize the standard criteria tests used to evaluate the measurement model. Cronbach's Alpha and Composite Reliability (CR) of 0.60 or greater are accepted. The Average
Variance Extracted (AVE) is another criterion for the assessment of the measurement model, and its accepted value is 0.5 or greater. As shown in Table II, the criteria of the measurement model of all construct items meet the standard criteria. Figure 5 presents the study measurement model.

TABLE II. THE CRITERIA OF THE MEASUREMENT MODEL

\begin{tabular}{|c|c|c|}
\hline Types of Analysis & Test name & Standard criteria \\
\hline \multirow{2}{*}{$\begin{array}{l}\text { Reliability of } \\
\text { internal consistency }\end{array}$} & $\begin{array}{l}\text { Cronbach's } \\
\text { alpha }\end{array}$ & $\geq 0.6$ acceptable \\
\hline & $\begin{array}{l}\text { Composite } \\
\text { reliability }\end{array}$ & $\geq 0.6$ acceptable \\
\hline \multirow{2}{*}{ Convergent validity } & Factor loading & $\geq 0.7$ acceptable \\
\hline & AVE & $\geq 0.5$ acceptable \\
\hline $\begin{array}{l}\text { Discriminant } \\
\text { validity }\end{array}$ & Cross loading & $\begin{array}{l}\text { The outer loading of each construct } \\
\text { should be more than the cross loading } \\
\text { of the next constructs }\end{array}$ \\
\hline
\end{tabular}

\section{1) Reliability of Internal Consistency}

The reliability of internal consistency of the constructs was the first indicator that was evaluated. Moreover, composite reliability test and Cronbach's alpha test were used. Cronbach's alpha is a convenient test that uses inter-correlations to estimate the reliability indicator variables. The second test composites reliability which is considered another measure for the reliability of internal consistency that takes into consideration the different outer loading of indicator variables. Cronbach's alpha and composite reliability should be more than or equal to 0.60 for each construct [73]. As shown in Table III, the result of both tests indicated the reliability of internal consistency.

TABLE III. RELIABILITY OF INTERNAL CONSISTENCY

\begin{tabular}{|c|c|c|c|}
\hline Construct name & $\begin{array}{c}\text { Constuct } \\
\text { code }\end{array}$ & $\begin{array}{c}\text { Cronbach's } \\
\text { alpha }\end{array}$ & $\begin{array}{c}\text { Composite } \\
\text { reliability }\end{array}$ \\
\hline Availability of Content & AOC & 0.952 & 0.959 \\
\hline Design & D & 0.954 & 0.961 \\
\hline Efficiency & E & 0.929 & 0.945 \\
\hline Interaction & I & 0.922 & 0.939 \\
\hline Information Quality & IQ & 0.892 & 0.921 \\
\hline Navigation & N & 0.916 & 0.947 \\
\hline Portal Service Quality & PSQ & 0.953 & 0.962 \\
\hline Portal User Support & PUS & 0.967 & 0.972 \\
\hline Student Portal Usage & SPU & 0.942 & 0.954 \\
\hline User Intention & UI & 0.933 & 0.946 \\
\hline User Satisfaction & US & 0.964 & 0.97 \\
\hline
\end{tabular}

\section{2) Convergent Validity}

According to [67], the convergent validity indicates the degree of which alternative procedures for the same construct are correlated positively. In this regard, there are two tests: the AVE and outer loadings of indicators that should be taken into account in this stage to evaluate the convergent validity of the constructs. Outer loading value should be 0.7 and above [67]. The AVE value for each construct should be 0.5 and above [67-69] as shown in Table IV.

\section{3) Discriminant Validity}

Discriminant validity is defined the as the degree of which a specific construct is different from others [73]. Cross loadings is the first measure to evaluate the discriminant validity indicators. The outer loadings indicators should be greater than 
any of its correlations to other constructs (see Appendix A). Fornell-Larcker is the second measure to evaluate discriminant validity. It compares the square root of the AVE values with the construct correlations. Fornell-Larcker criterion determines whether the AVE is bigger than the squared construct correlation with the other constructs [67]. The Fornell-Larcker results satisfy the criterion (Appendix B).

TABLE IV. CONVERGENT VALIDITY TESTS

\begin{tabular}{|c|c|c|c|}
\hline Independent variable & Items & Loading & AVE \\
\hline \multirow[t]{5}{*}{ 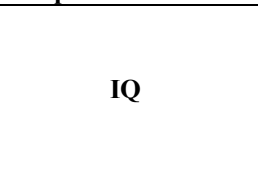 } & IQ1 & 0.804 & 0.699 \\
\hline & IQ2 & 0.847 & \\
\hline & IQ3 & 0.9 & \\
\hline & IQ4 & 0.842 & \\
\hline & IQ5 & 0.783 & \\
\hline \multirow{9}{*}{ AOC } & $\mathrm{AOC} 2$ & 0.811 & 0.724 \\
\hline & AOC3 & 0.775 & \\
\hline & $\mathrm{AOC} 4$ & 0.879 & \\
\hline & AOC5 & 0.864 & \\
\hline & AOC6 & 0.836 & \\
\hline & $\mathrm{AOC7}$ & 0.852 & \\
\hline & AOC 8 & 0.883 & \\
\hline & AOC9 & 0.862 & \\
\hline & $\mathrm{AOC} 11$ & 0.888 & \\
\hline \multirow{6}{*}{$\mathbf{I}$} & $\mathrm{I} 2$ & 0.785 & 0.721 \\
\hline & $\mathrm{I} 3$ & 0.842 & \\
\hline & $\mathrm{I} 5$ & 0.897 & \\
\hline & I6 & 0.86 & \\
\hline & 17 & 0.842 & \\
\hline & I8 & 0.864 & \\
\hline \multirow{3}{*}{$\mathbf{N}$} & N1 & 0.916 & 0.856 \\
\hline & N3 & 0.94 & \\
\hline & $\mathrm{N} 4$ & 0.92 & \\
\hline \multirow{9}{*}{ D } & D2 & 0.805 & 0.733 \\
\hline & D3 & 0.871 & \\
\hline & D4 & 0.862 & \\
\hline & D8 & 0.871 & \\
\hline & D9 & 0.842 & \\
\hline & D10 & 0.859 & \\
\hline & D11 & 0.882 & \\
\hline & D12 & 0.846 & \\
\hline & D14 & 0.867 & \\
\hline \multirow{6}{*}{$\mathbf{E}$} & E1 & 0.764 & 0.741 \\
\hline & E2 & 0.867 & \\
\hline & E3 & 0.888 & \\
\hline & E4 & 0.868 & \\
\hline & E5 & 0.909 & \\
\hline & E6 & 0.861 & \\
\hline \multirow{7}{*}{ UI } & UI1 & 0.788 & 0.715 \\
\hline & UI2 & 0.846 & \\
\hline & UI3 & 0.837 & \\
\hline & UI4 & 0.889 & \\
\hline & UI5 & 0.869 & \\
\hline & UI6 & 0.852 & \\
\hline & UI7 & 0.833 & \\
\hline \multirow{7}{*}{ PSQ } & PSQ2 & 0.878 & 0.783 \\
\hline & PSQ3 & 0.758 & \\
\hline & PSQ4 & 0.906 & \\
\hline & PSQ5 & 0.883 & \\
\hline & PSQ6 & 0.915 & \\
\hline & PSQ7 & 0.928 & \\
\hline & PSQ8 & 0.918 & \\
\hline \multirow{3}{*}{ PUS } & PUS1 & 0.843 & 0.815 \\
\hline & PUS2 & 0.889 & \\
\hline & PUS3 & 0.919 & \\
\hline
\end{tabular}

\begin{tabular}{|l|c|c|c|}
\hline \multirow{5}{*}{} & PUS4 & 0.915 & \\
\cline { 2 - 4 } & PUS5 & 0.922 & \\
\hline & PUS6 & 0.905 & \\
\hline & PUS7 & 0.91 & \\
\hline & PUS8 & 0.918 & \\
\hline \multirow{5}{*}{ US } & US1 & 0.872 & 0.822 \\
\hline & US2 & 0.923 & \\
\cline { 2 - 4 } & US3 & 0.935 & \\
\cline { 2 - 4 } & US4 & 0.904 & \\
\cline { 2 - 4 } & US5 & 0.926 & \\
\hline & US6 & 0.895 & \\
\cline { 2 - 4 } & US7 & 0.891 & \\
\hline
\end{tabular}

\section{4) Goodness of Fit (GoF)}

GoF is a global fit measure [70]. It is the geometric mean of both the AVE and the average of $R^{2}$ of the endogenous variables [71]. The calculation formula of GoF is:

$$
G o F=\sqrt{\overline{R^{2} \times \overline{A V E}}}
$$

The criteria to determine whether GoF values are no fit, small, medium, or large to be considered as global valid PLS model [72] are shown in Table V.

TABLE V.
\begin{tabular}{|c|c|}
\hline$\leq 0.1$ & No fit \\
\hline 0.1 to 0.25 & Small \\
\hline 0.25 to 0.36 & Medium \\
\hline$\geq 0.36$ & Large \\
\hline
\end{tabular}

The value of the Gof of this study is 0.771 , which means the GoF model of this study is large enough to be considered of sufficient global PLS model validity.

The next stage examines the hypotheses of this study using the structural model. This stage tests the predictive capability of the model and the relationship between the constructs. The path coefficients of the structural model are determined after the collinearity assessment, which represents the relationship of the hypotheses among the structural model constructs. The standardized values of the path coefficients are between -1 and +1 . If the path coefficients are close to 1 , it means that there is a strong and statistically significant positive relationship among the constructs. If the path coefficients are close to 0 , then the relationship between the constructs is considered weak [68]. In this study, the one-tailed test was used because the relationships of the hypotheses are positive and direct. The critical values and $p$-values for one-tailed tests are 1.28 (with significance level=10\%), 1.65 (with significance level=5\%), and 2.33 (with significance level=1\%) [67] as shown in Table VI. Figure 6 presents the path coefficients of the structural model using smartPLS3.

TABLE VI. PATH RELATIONSHIPS

\begin{tabular}{|c|c|c|}
\hline Analysis & Test & Standard \\
\hline \multirow{4}{*}{ Path relationship } & \multirow{2}{*}{ p value } & $*<0.10$ \\
& & $* *<0.05$ \\
\cline { 2 - 3 } & \multirow{2}{*}{$\mathrm{t}$ value } & $>1.28$ level of significance $=10 \%$ \\
& & $>1.96$ level of significance $=5 \%$ \\
& $>2.33$ level of significance $=1 \%$ \\
\hline
\end{tabular}




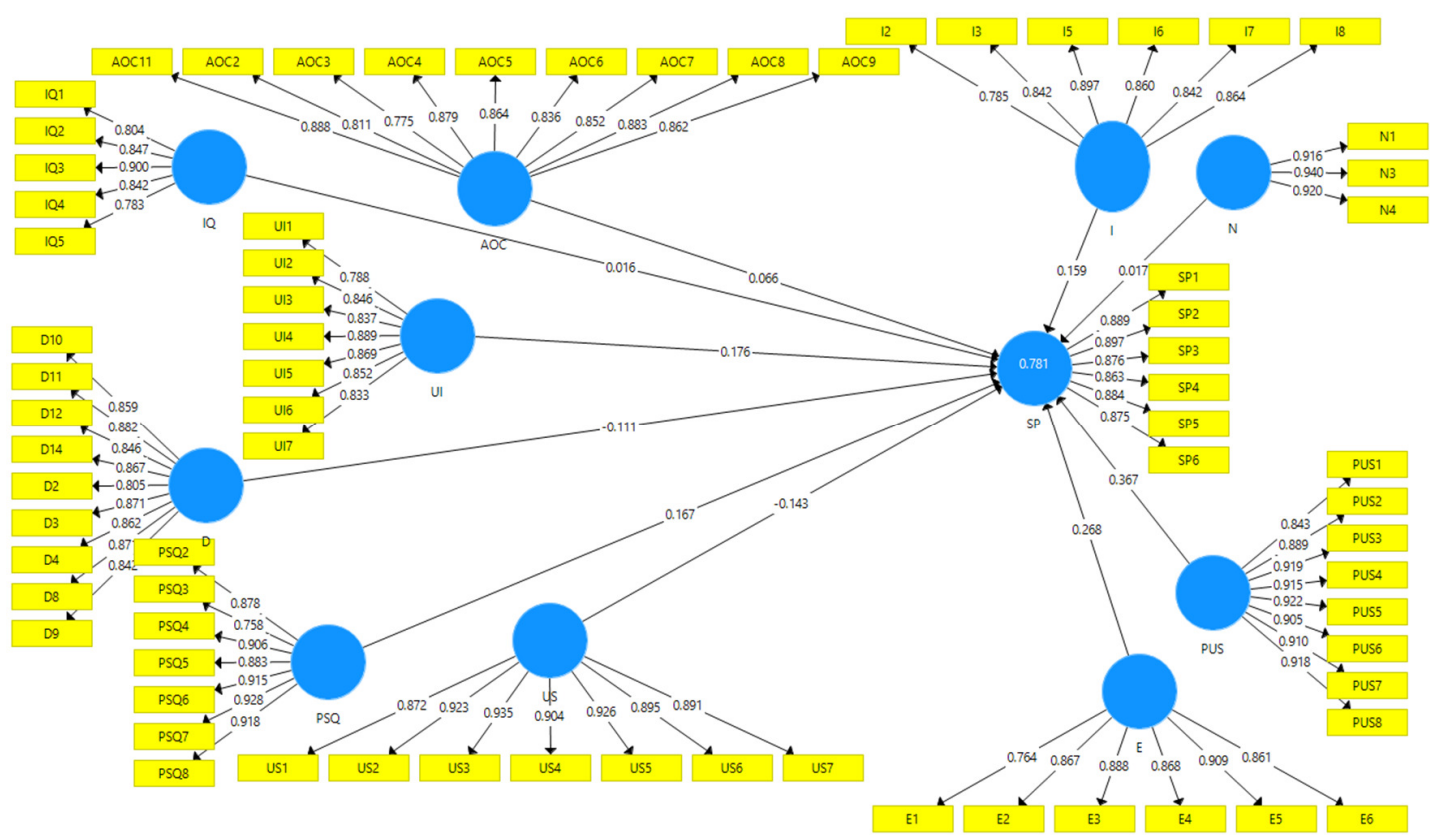

Fig. 5. Study measurement model.

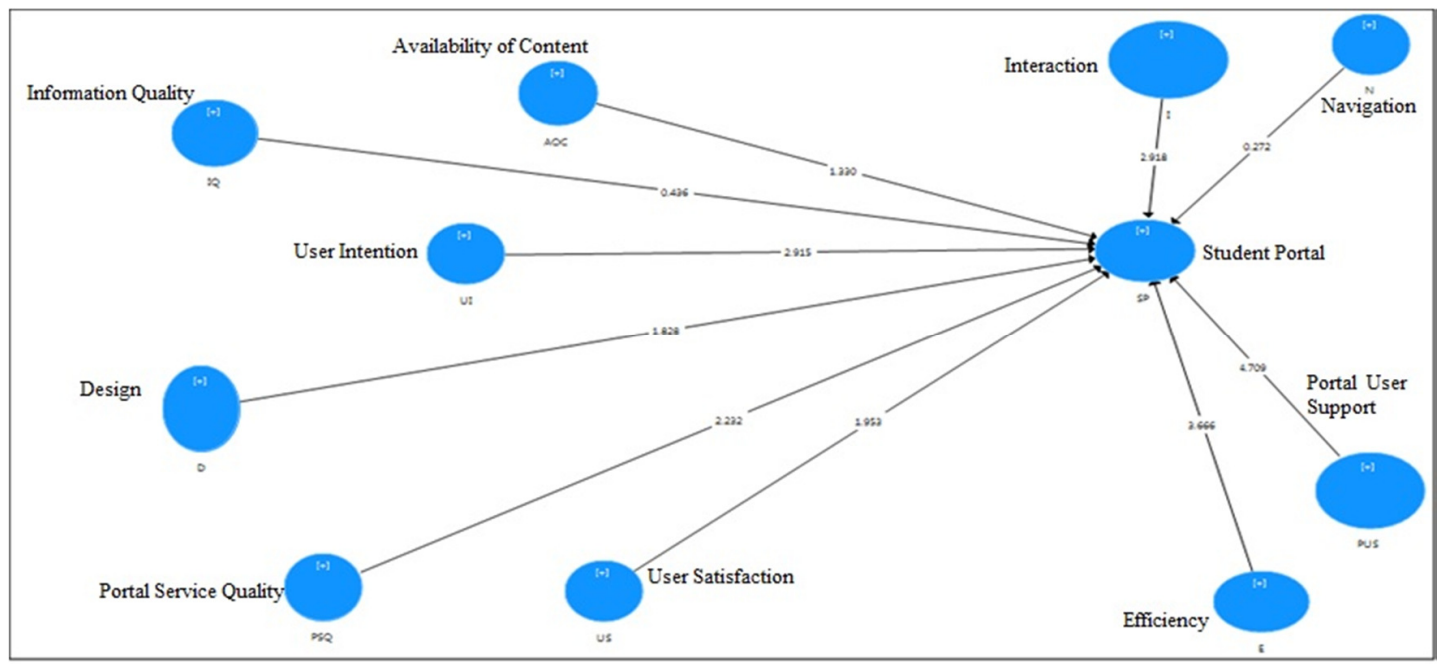

Fig. 6. Path coefficients of the structural model.

TABLE VII. RESULTS OF HYPOTHESIS TESTING

\begin{tabular}{|c|c|c|c|c|}
\hline Factor path & t value & p value & Significant level & Decision \\
\hline $\mathrm{AOC} \rightarrow \mathrm{SP}$ & 1.33 & 0.092 & $*$ & Supported \\
\hline $\mathrm{D} \rightarrow \mathrm{SP}$ & 1.828 & 0.034 & $* *$ & Supported \\
\hline $\mathrm{E} \rightarrow \mathrm{SP}$ & 3.666 & 0 & $* * *$ & Supported \\
\hline $\mathrm{I} \rightarrow \mathrm{SP}$ & 2.918 & 0.002 & $* * *$ & Supported \\
\hline $\mathrm{IQ} \rightarrow \mathrm{SP}$ & 0.436 & 0.331 & NS & Not supported \\
\hline $\mathrm{N} \rightarrow \mathrm{SP}$ & 0.272 & 0.393 & NS & Not supported \\
\hline $\mathrm{PSQ} \rightarrow \mathrm{SP}$ & 2.232 & 0.013 & $* * *$ & Supported \\
\hline $\mathrm{PUS} \rightarrow \mathrm{SP}$ & 4.709 & 0 & $* * *$ & Supported \\
\hline $\mathrm{UI} \rightarrow \mathrm{SP}$ & 2.915 & 0.002 & $* * *$ & Supported \\
\hline $\mathrm{US} \rightarrow \mathrm{SP}$ & 1.953 & 0.025 & $* *$ & Supported \\
\hline
\end{tabular}

The result of hypotheses testing shows that most of the hypotheses are significant. Moreover, by using a bootstrapping test in smart-PLS, the result shows that 8 out of 10 hypotheses are significant. Table VII presents the results of hypotheses testing.

As presented above, this study has 10 hypotheses. Ha1 stated that US has a significant and positive affect on students' use of the student portal. Previous studies indicated that the satisfaction of users will provide a surrogate which is significant to the critical product of the existing or new information system [30]. US is in terms of the use of the system and the acceptance of the portal, which is important in measuring the success of the information system [73]. Therefore, in this study, US about the portal is considered significant based on preliminary studies and the final result of data collection which reveals that there is a positive relationship between US and the use of the student portal (tvalue $=1.953$, $p$-value $=0.018)$. Saudi universities should take 
into account the US when they improve their portals based on their students' needs and demands.

$\mathrm{Ha} 2$ states that IQ has a positive effect on students' use of the student portal. According to [38], IQ is the output quality of an information system, which reflects dimensions such as content, accuracy, timing, and format. It is an important factor because providing high-quality information to users in a university student portal can help in delivering innovative services to students. The results show a negative relationship between IQ and the use of the students' portal ( $\mathrm{t}$-value $=0.436$, $p$-value $=0.331$ ) because the student portal does not create new information nor meet students' needs based on students' point of view. However, the quality of the information provided on the portal should meet the students' needs. Thus, universities in Saudi Arabia have to improve their student portals based on their students' needs and demands.

$\mathrm{Ha} 3$ states that Interaction has a positive and significant effect on students' use of the student portal. Authors in [35] defined interaction as the ease by which users interact with the input and output of the system and their ability to learn through it. Interaction is one of the main factors that contribute to positive learning outcomes in a learning environment [74]. The findings of this study reveal that there is a positive relationship between Interaction and using the student portal ( $\mathrm{t}-$ value $=2.918$, $\mathrm{p}$-value $=0.002$ ). Thus, Interaction is considered an important indicator that can help improve student portal usage.

Ha4 states that the AOC has a positive effect on students' use of the student portal [37]. This is shaped by the educational and non-educational services provided in the portal, such as online library services, email services, lecturer evaluation, and registration services. A student portal should facilitate easy access to all services and be flexible, quick, and allow users to perform their tasks [38]. The findings of this study showed that there is a positive relationship between the availability of content and the usage of the student portals ( $\mathrm{t}$-value $=1.33$, $\mathrm{p}$ value $=0.092$ ). Thus, the AOC will help Saudi universities to improve their student portals based on their students' demands and expectations.

Ha5 states that PSQ has a significant and positive effect on students' use of the student portal. The author in [40] defined PSQ as a measure of the level of customers' expectations with how well the information system offers services to users. Service quality within the context of the portal can be determined by prompt, responsive, available, accessible, and flexible e-services [41]. Therefore, PSQ is a key determinant for the use and US about e-services provided via a portal [42]. The result of this study reveals a positive relationship between PSQ and the use of a students' portal ( $\mathrm{t}$-value=2.232, pvalue $=0.013$ ). Thus, PSQ is a significant indicator that can help Saudi universities improve their student portals.

Ha6 states that portal design has a significant and positive effect on the use of the student portal. According to [75], university student portals are designed to make the member's experience with the portal as personalized as possible. The design features that attract users and increase their satisfaction include enjoyment, excitement, participation, and charm [45].
Design can motivate them to participate and promote excitement to enjoy while visiting the website. Therefore, student portal design features that help students to enjoy their visit lead to increased activity [46]. This study reveals that there is a positive relationship between design and use of the students' portal (t-value $=1.828, \mathrm{p}$-value $=0.034)$. Thus, the portal design is paramount to improving student portal usage.

HA7 states that navigation has a positive effect on students' use of the student portal. Usually, a navigation bar offers the main tasks of the website [76]. According to [47], navigation is a significant factor in learning the web portal. Users should be able to move through portal links without getting lost. The ease of navigation is a critical component of portal usage [48]. The result of this study shows that there is a negative relationship between Navigation and use of portals (t-value $=0.272$, pvalue $=0.393$ ) which means that Navigation is not regarded as an essential predictor for the use of a student portal from the viewpoint of students. Anyhow, the student portal navigation does not attract students or meet their needs, so it will be useful for Saudi universities to improve it, provide more links that students need in their study, and make the portal easier to use and easier to find the necessary information.

$\mathrm{Ha} 8$ states that PUS has a significant and positive effect on students' use of the student portal. Authors in [51] define user support as the ability of the IT department to assist users when needed. Moreover, because an academic portal is usually complex and needs qualified staff, it is necessary to have online user support tools to help the users [28]. Students (users) should be given specified training and user support, to increase the ease of use and learnability to effectively and efficiently fulfil a specified range of task scenarios on the web portal while management achieves their economic and global attainments [77]. This study reveals that there is a positive relationship between PUS and the use of the student portals ( $\mathrm{t}$ value $=4.709$, $p$-value $=0$ ).

Hypothesis $\mathrm{Hb} 1$ states that Efficiency has a significant and positive effect on students' use of the student portal. As a personal factor, Efficiency is defined as the judgements of people on their capabilities to organize and implement the required courses of action to achieve a required goal [52]. Efficiency was shown to be an important indicator that determines the actual behavior of a person [78]. Furthermore, the student portal is a good learning environment [38]. Even though student portals offer good information, their efficiency will decrease if the student ability does not meet the suitable level [54]. This study reveals that there is a positive relationship between the efficiency factor and the use of students' portals (t-value $=3.666$, $\mathrm{p}$-value $=0$ ).

The last hypothesis is that UI has a significant impact on students' use of the student portal. Moreover, as a behavioral factor, UI is defined as a person's ability to formulate clear plans to perform a determined future behaviour [55]. Many factors might affect students' behavioral intention to use the student portal. Behavioral intention predicts or at least is linked with the actual usage $[57,58]$. This study revealed that there is a positive relationship between UI and using the students' portal $(\mathrm{t}$-value $=2.915$, $\mathrm{p}$-value $=0.002)$. 
This study developed and validated a model based on data collected via a survey of students in 4 Saudi universities. SmartPLS3 was used to analyze the data. The findings indicate that 8 out of 10 considered factors are significant and have a positive effect on student portal usage. These factors are User Satisfaction, Design, Availability Of Content, User Intention, Efficiency, Portal User Support, Portal Service Quality, and Interaction. On the other hand, Information Quality and Navigation had no significant effect on portal usage. The model was able to discover students' expectations about the portals of Saudi universities, so it can help them to imrove their students' portal usage. Figure 7, presents the model of this study along with the significance results.

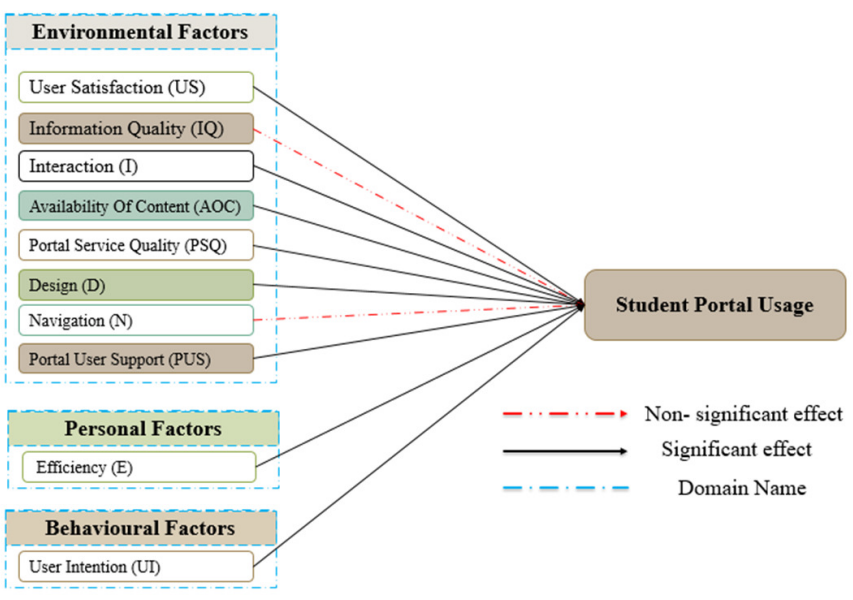

Fig. 7. The model of this study.

The model of this study has established the context of what students need to use the university portals. This model recommends university management and IT departments to provide an appropriate electronic e-service and suitable ICT environment that support the portal users. The model of this study also identified the most important factors that affect the students to use the portals. By taking into account these factors in the portal development process, universities can improve their portals. In addition, this study is one of the few studies that provide the factors that help universities build suitable electronic systems to develop and improve their university portal usage.

\section{CONCLUSION AND FUTURE WORK}

This study studied the importance of student portals by investigating the most important factors that attract undergraduate students in Saudi universities to use them. The authors divided the identified factors into environmental, personal, and behavioral. Each category included sub-factors. The environmental category included 8 , the personal category included 1 , and the behavioral category also included 1 . This study found that the 3 categories positively affect students' portal usage. Moreover, the 10 hypotheses regarding the factors and their results presented the relationship between independent variables and the dependent variable, which indicates that UI, D, AOC, UI, E, PUS, PSQ, and I have a positive effect on students' use of the student portal. On the other hand, IQ and $\mathrm{N}$ do not have a significant effect on students' portal usage. Future work can investigate these factors from other perspectives, such as the academic and administrative staff point of views. This study was conducted on undergraduate students in Saudi Arabia universities. Future work can extend and consider postgraduate students. This study can be considered a good start for researchers to investigate more on the usage of electronic resources and ICT in university portals to improve the needs of other university users.

\section{APPENDIX A}

Cross Loadings of Discriminant Validity

\begin{tabular}{|l|l|l|l|l|l|l|l|l|l|l|} 
AOC & D & E & I & IO & N & PSO & PUS & SPU & UI & US \\
\hline
\end{tabular}

\begin{tabular}{c|c|c|c|c|c|c|c|c|c|c|c|} 
AOC2 & 0.811 & 0.611 & 0.593 & 0.605 & 0.592 & 0.662 & 0.658 & 0.511 & 0.58 & 0.581 & 0.63
\end{tabular} \begin{tabular}{|l|l|l|l|l|l|l|l|l|l|l|l|}
\hline AOC3 & 0.775 & 0.512 & 0.526 & 0.667 & 0.528 & 0.543 & 0.543 & 0.426 & 0.553 & 0.552 & 0.503 \\
\hline .
\end{tabular} \begin{tabular}{|l|l|l|l|l|l|l|l|l|l|l|l|} 
AOC4 & 0.879 & 0.589 & 0.591 & 0.666 & 0.598 & 0.701 & 0.621 & 0.531 & 0.603 & 0.58 & 0.605 \\
\hline
\end{tabular} \begin{tabular}{|l|l|l|l|l|l|l|l|l|l|l|l|l|l|}
\hline AOC5 & 0.864 & 0.626 & 0.625 & 0.638 & 0.533 & 0.669 & 0.645 & 0.585 & 0.602 & 0.638 & 0.64
\end{tabular} \begin{tabular}{|l|l|l|l|l|l|l|l|l|l|l|l|l|}
\hline AOC6 & 0.836 & 0.623 & 0.578 & 0.616 & 0.503 & 0.611 & 0.596 & 0.535 & 0.568 & 0.585 & 0.617 \\
\hline AOC7 & 0.852 & 0.655 & 0.604 & 0.672 & 0.553 & 0.657 & 0.61 & 0.535 & 0.573 & 0.607 & 0.607 \\
\hline
\end{tabular} \begin{tabular}{|l|l|l|l|l|l|l|l|l|l|l|l|}
\hline AOC7 & 0.852 & 0.655 & 0.604 & 0.672 & 0.553 & 0.657 & 0.61 & 0.535 & 0.573 & 0.607 & 0.607
\end{tabular} \begin{tabular}{|l|l|l|l|l|l|l|l|l|l|l|l|l|} 
AOC8 & 0.883 & 0.662 & 0.625 & 0.681 & 0.571 & 0.723 & 0.654 & 0.586 & 0.623 & 0.608 & 0.657 \\
\hline
\end{tabular} \begin{tabular}{|l|l|l|l|l|l|l|l|l|l|l|l|l|}
\hline AOC9 & 0.862 & 0.648 & 0.648 & 0.689 & 0.597 & 0.663 & 0.629 & 0.619 & 0.667 & 0.666 & 0.65 \\
\hline
\end{tabular} \begin{tabular}{|l|l|l|l|l|l|l|l|l|l|l|l|l|l|}
\hline AOC11 & 0.888 & 0.645 & 0.633 & 0.655 & 0.556 & 0.712 & 0.656 & 0.619 & 0.616 & 0.676 & 0.669 \\
\hline
\end{tabular} \begin{tabular}{ll|l|l|l|l|l|l|l|l|l|l|l|l|l|l|l|l} 
D2 & 0.598 & 0.805 & 0.592 & 0.611 & 0.464 & 0.591 & 0.601 & 0.555 & 0.544 & 0.614 & 0.609 \\
\hline
\end{tabular} \begin{tabular}{|l|l|l|l|l|l|l|l|l|l|l|l|l|l|l|} 
D3 & 0.645 & 0.871 & 0.671 & 0.641 & 0.538 & 0.658 & 0.652 & 0.616 & 0.603 & 0.672 & 0.68 \\
\hline
\end{tabular} \begin{tabular}{l|l|l|l|l|l|l|l|l|l|l|l|l|l|l|l|} 
D4 & 0.614 & 0.862 & 0.627 & 0.633 & 0.503 & 0.63 & 0.662 & 0.573 & 0.584 & 0.653 & 0.687 \\
\hline
\end{tabular} \begin{tabular}{l|l|l|l|l|l|l|l|l|l|l|l|l|l|l} 
D8 & 0.692 & 0.871 & 0.664 & 0.679 & 0.514 & 0.681 & 0.727 & 0.593 & 0.591 & 0.688 & 0.735 \\
\hline
\end{tabular} \begin{tabular}{|l|l|l|l|l|l|l|l|l|l|l|l|l|} 
D9 & 0.55 & 0.842 & 0.611 & 0.565 & 0.455 & 0.566 & 0.62 & 0.571 & 0.562 & 0.659 & 0.64 \\
\hline
\end{tabular} \begin{tabular}{l|l|l|l|l|l|l|l|l|l|l|l|l|l|} 
D10 & 0.615 & 0.859 & 0.65 & 0.631 & 0.56 & 0.635 & 0.636 & 0.616 & 0.631 & 0.688 & 0.637
\end{tabular} \begin{tabular}{l|l|l|l|l|l|l|l|l|l|l|l|l|} 
D11 & 0.633 & 0.882 & 0.661 & 0.632 & 0.49 & 0.671 & 0.669 & 0.59 & 0.602 & 0.698 & 0.681 \\
\hline
\end{tabular} \begin{tabular}{l|l|l|l|l|l|l|l|l|l|l|l|l|l|} 
D12 & 0.666 & 0.846 & 0.686 & 0.642 & 0.472 & 0.679 & 0.663 & 0.638 & 0.587 & 0.629 & 0.677 \\
\hline
\end{tabular} \begin{tabular}{l|l|l|l|l|l|l|l|l|l|l|l|l|l|} 
D14 & 0.6 & 0.867 & 0.679 & 0.612 & 0.431 & 0.666 & 0.692 & 0.623 & 0.594 & 0.677 & 0.72 \\
\hline
\end{tabular} \begin{tabular}{l|l|l|l|l|l|l|l|l|l|l|l|} 
E1 & 0.541 & 0.605 & 0.764 & 0.561 & 0.498 & 0.573 & 0.599 & 0.635 & 0.645 & 0.649 & 0.611 \\
\hline
\end{tabular} \begin{tabular}{|l|l|l|l|l|l|l|l|l|l|l|l|l|} 
E2 & 0.628 & 0.677 & 0.867 & 0.602 & 0.443 & 0.647 & 0.755 & 0.723 & 0.69 & 0.658 & 0.787 \\
\hline
\end{tabular} \begin{tabular}{|l|l|l|l|l|l|l|l|l|l|l|l|l|l|} 
E3 & 0.635 & 0.697 & 0.888 & 0.63 & 0.509 & 0.659 & 0.7 & 0.73 & 0.7 & 0.675 & 0.75 \\
\hline
\end{tabular} \begin{tabular}{|l|l|l|l|l|l|l|l|l|l|l|l|l|} 
E4 & 0.619 & 0.618 & 0.868 & 0.582 & 0.436 & 0.561 & 0.677 & 0.726 & 0.718 & 0.666 & 0.739 \\
\hline
\end{tabular} \begin{tabular}{l|l|l|l|l|l|l|l|l|l|l|l|l|l|} 
E5 & 0.647 & 0.683 & 0.909 & 0.629 & 0.49 & 0.657 & 0.754 & 0.746 & 0.731 & 0.708 & 0.805 \\
\hline
\end{tabular} \begin{tabular}{ll|l|l|l|l|l|l|l|l|l|l|l|l|l|} 
E6 & 0.592 & 0.637 & 0.861 & 0.582 & 0.501 & 0.594 & 0.645 & 0.736 & 0.742 & 0.704 & 0.69
\end{tabular}

\begin{tabular}{l|l|l|l|l|l|l|l|l|l|l|l|} 
I2 & 0.62 & 0.585 & 0.521 & 0.785 & 0.514 & 0.565 & 0.589 & 0.51 & 0.537 & 0.607 & 0.544 \\
\hline
\end{tabular} \begin{tabular}{|l|l|l|l|l|l|l|l|l|l|l|l|} 
I3 & 0.606 & 0.57 & 0.519 & 0.842 & 0.558 & 0.591 & 0.536 & 0.474 & 0.612 & 0.613 & 0.535 \\
\hline
\end{tabular} \begin{tabular}{l|l|l|l|l|l|l|l|l|l|l|l|l|} 
I5 & 0.69 & 0.619 & 0.58 & 0.897 & 0.53 & 0.679 & 0.601 & 0.527 & 0.615 & 0.652 & 0.579 \\
\hline
\end{tabular} \begin{tabular}{|c|c|c|c|c|c|c|c|c|c|c|c|} 
I6 & 0.62 & 0.608 & 0.587 & 0.86 & 0.543 & 0.69 & 0.578 & 0.549 & 0.589 & 0.59 & 0.58 \\
\hline
\end{tabular} \begin{tabular}{l|l|l|l|l|l|l|l|l|l|l|l|} 
I7 & 0.667 & 0.659 & 0.636 & 0.842 & 0.495 & 0.732 & 0.637 & 0.597 & 0.66 & 0.629 & 0.623 \\
\hline
\end{tabular} \begin{tabular}{l|l|l|l|l|l|l|l|l|l|l|l|l|l|}
\hline I8 & 0.711 & 0.683 & 0.68 & 0.864 & 0.518 & 0.728 & 0.691 & 0.59 & 0.653 & 0.645 & 0.663 \\
\hline
\end{tabular} \begin{tabular}{l|l|l|l|l|l|l|l|l|l|l|l|l|l|}
\hline IQ1 & 0.575 & 0.501 & 0.508 & 0.535 & 0.804 & 0.489 & 0.493 & 0.478 & 0.523 & 0.523 & 0.49 \\
\hline
\end{tabular} \begin{tabular}{l|l|l|l|l|l|l|l|l|l|l|l|} 
IQ2 & 0.546 & 0.442 & 0.436 & 0.499 & 0.847 & 0.434 & 0.408 & 0.376 & 0.428 & 0.47 & 0.406 \\
\hline
\end{tabular} \begin{tabular}{l|l|l|l|l|l|l|l|l|l|l|l|l|}
\hline IQ3 & 0.594 & 0.522 & 0.505 & 0.541 & 0.9 & 0.498 & 0.483 & 0.444 & 0.495 & 0.534 & 0.47 \\
\hline
\end{tabular} \begin{tabular}{|l|l|l|l|l|l|l|l|l|l|l|l|l|} 
IQ4 & 0.518 & 0.459 & 0.46 & 0.502 & 0.842 & 0.449 & 0.42 & 0.399 & 0.465 & 0.479 & 0.418 \\
\hline
\end{tabular} \begin{tabular}{|l|l|l|l|l|l|l|l|l|l|l|l|}
\hline IQ5 & 0.505 & 0.472 & 0.399 & 0.505 & 0.783 & 0.367 & 0.4 & 0.381 & 0.396 & 0.489 & 0.372 \\
\hline
\end{tabular} \begin{tabular}{l|l|l|l|l|l|l|l|l|l|l|l|} 
N1 & 0.714 & 0.69 & 0.653 & 0.722 & 0.527 & 0.916 & 0.667 & 0.595 & 0.642 & 0.653 & 0.657 \\
\hline
\end{tabular} \begin{tabular}{|l|l|l|l|l|l|l|l|l|l|l|l|l|l|}
$\mathbf{N 3}$ & 0.716 & 0.677 & 0.658 & 0.74 & 0.498 & 0.94 & 0.683 & 0.612 & 0.663 & 0.643 & 0.664 \\
\hline
\end{tabular} \begin{tabular}{l|l|l|l|l|l|l|l|l|l|l|l|l|l|} 
N4 & 0.729 & 0.717 & 0.674 & 0.719 & 0.473 & 0.92 & 0.696 & 0.624 & 0.633 & 0.671 & 0.669 \\
\hline
\end{tabular} \begin{tabular}{|c|c|c|c|c|c|c|c|c|c|c|c|c|}
\hline PSQ2 & 0.676 & 0.7 & 0.731 & 0.678 & 0.478 & 0.711 & 0.878 & 0.621 & 0.675 & 0.738 & 0.792 \\
\hline
\end{tabular} \begin{tabular}{|l|l|l|l|l|l|l|l|l|l|l|l|l|}
\hline PSQ3 & 0.574 & 0.642 & 0.635 & 0.632 & 0.498 & 0.572 & 0.758 & 0.62 & 0.7 & 0.702 & 0.661 \\
\hline
\end{tabular} \begin{tabular}{|l|l|l|l|l|l|l|l|l|l|l|l|l|l|} 
PSQ4 & 0.656 & 0.681 & 0.703 & 0.651 & 0.46 & 0.661 & 0.906 & 0.641 & 0.663 & 0.676 & 0.798 \\
\hline
\end{tabular} \begin{tabular}{|l|l|l|l|l|l|l|l|l|l|l|l|l|l|}
\hline PSQ5 & 0.66 & 0.685 & 0.684 & 0.617 & 0.477 & 0.649 & 0.883 & 0.605 & 0.619 & 0.647 & 0.772 \\
\hline
\end{tabular} \begin{tabular}{|l|l|l|l|l|l|l|l|l|l|l|l|l|l|l|l|l|l|}
\hline PSQ6 & 0.644 & 0.656 & 0.701 & 0.599 & 0.451 & 0.622 & 0.915 & 0.615 & 0.638 & 0.663 & 0.803 \\
\hline
\end{tabular} \begin{tabular}{|l|l|l|l|l|l|l|l|l|l|l|l|} 
PSQ7 & 0.658 & 0.686 & 0.742 & 0.625 & 0.446 & 0.676 & 0.928 & 0.642 & 0.67 & 0.68 & 0.827 \\
\hline
\end{tabular} \begin{tabular}{|l|l|l|l|l|l|l|l|l|l|l|l|l|l|}
\hline PSQ8 & 0.668 & 0.698 & 0.751 & 0.609 & 0.468 & 0.661 & 0.918 & 0.648 & 0.664 & 0.669 & 0.845 \\
\hline
\end{tabular} \begin{tabular}{|l|l|l|l|l|l|l|l|l|l|l|l|}
\hline PUS1 & 0.615 & 0.633 & 0.746 & 0.551 & 0.47 & 0.608 & 0.622 & 0.843 & 0.714 & 0.634 & 0.679 \\
\hline
\end{tabular} \begin{tabular}{|l|l|l|l|l|l|l|l|l|l|l|l|l|} 
PUS2 & 0.638 & 0.634 & 0.768 & 0.622 & 0.481 & 0.624 & 0.644 & 0.889 & 0.771 & 0.679 & 0.682
\end{tabular} \begin{tabular}{|l|l|l|l|l|l|l|l|l|l|l|l|l|l|l|}
\hline PUS3 & 0.578 & 0.654 & 0.759 & 0.585 & 0.431 & 0.595 & 0.64 & 0.919 & 0.728 & 0.661 & 0.693 \\
\hline
\end{tabular} \begin{tabular}{|l|l|l|l|l|l|l|l|l|l|l|l|}
\hline PUS4 & 0.576 & 0.618 & 0.752 & 0.563 & 0.445 & 0.568 & 0.634 & 0.915 & 0.716 & 0.647 & 0.656 \\
\hline
\end{tabular} \begin{tabular}{|l|l|l|l|l|l|l|l|l|l|l|l|l|l|} 
PUS5 & 0.606 & 0.654 & 0.791 & 0.609 & 0.472 & 0.623 & 0.675 & 0.922 & 0.769 & 0.694 & 0.714
\end{tabular} \begin{tabular}{|l|c|c|c|c|c|c|c|c|c|c|c|c|c|}
\hline PUS6 & 0.543 & 0.654 & 0.745 & 0.549 & 0.413 & 0.562 & 0.648 & 0.905 & 0.7 & 0.628 & 0.7 \\
\hline
\end{tabular} \begin{tabular}{l|l|l|l|l|l|l|l|l|l|l|l|l|l|} 
PUS7 & 0.551 & 0.584 & 0.712 & 0.556 & 0.428 & 0.586 & 0.621 & 0.91 & 0.743 & 0.651 & 0.649 \\
\hline
\end{tabular} \begin{tabular}{|l|l|l|l|l|l|l|l|l|l|l|l|l|}
\hline PUS8 & 0.575 & 0.608 & 0.743 & 0.575 & 0.474 & 0.593 & 0.652 & 0.918 & 0.747 & 0.637 & 0.675 \\
\hline
\end{tabular} \begin{tabular}{l|l|l|l|l|l|l|l|l|l|l|l|l|l|l|}
\hline SPU1 & 0.647 & 0.625 & 0.737 & 0.65 & 0.504 & 0.653 & 0.656 & 0.717 & 0.889 & 0.685 & 0.657 \\
\hline
\end{tabular} \begin{tabular}{|l|l|l|l|l|l|l|l|l|l|l|l|l|l|l|l|}
\hline SPU2 & 0.647 & 0.599 & 0.726 & 0.648 & 0.487 & 0.643 & 0.649 & 0.709 & 0.897 & 0.678 & 0.633 \\
\hline
\end{tabular} \begin{tabular}{|l|l|l|l|l|l|l|l|l|l|l|l|}
\hline SPU3 & 0.55 & 0.542 & 0.662 & 0.584 & 0.468 & 0.535 & 0.578 & 0.674 & 0.876 & 0.629 & 0.562 \\
\hline
\end{tabular} 
\begin{tabular}{l|l|l|l|l|l|l|l|l|l|l|l|}
\hline SPU4 & 0.553 & 0.556 & 0.649 & 0.611 & 0.487 & 0.547 & 0.598 & 0.662 & 0.863 & 0.653 & 0.575 \\
\hline
\end{tabular}

\begin{tabular}{l|l|l|l|l|l|l|l|l|l|l|l|l|} 
SPU5 & 0.657 & 0.642 & 0.768 & 0.645 & 0.493 & 0.634 & 0.724 & 0.768 & 0.884 & 0.697 & 0.728 \\
\hline
\end{tabular}

\begin{tabular}{|l|l|l|l|l|l|l|l|l|l|l|l|}
\hline SPU6 & 0.654 & 0.656 & 0.771 & 0.668 & 0.498 & 0.659 & 0.738 & 0.768 & 0.875 & 0.722 & 0.728 \\
\hline
\end{tabular}

\begin{tabular}{l|l|l|l|l|l|l|l|l|l|l|l|l|l|} 
UI1 & 0.641 & 0.724 & 0.692 & 0.607 & 0.455 & 0.663 & 0.755 & 0.612 & 0.615 & 0.788 & 0.768 \\
\hline
\end{tabular}

\begin{tabular}{ll|l|l|l|l|l|l|l|l|l|l|l|l|l|l|} 
UI2 & 0.665 & 0.708 & 0.684 & 0.638 & 0.486 & 0.686 & 0.709 & 0.63 & 0.638 & 0.846 & 0.727 \\
\hline
\end{tabular}

\begin{tabular}{l|l|l|l|l|l|l|l|l|l|l|l|} 
UI3 & 0.515 & 0.565 & 0.598 & 0.566 & 0.478 & 0.511 & 0.547 & 0.555 & 0.636 & 0.837 & 0.55 \\
\hline
\end{tabular}

\begin{tabular}{l|l|l|l|l|l|l|l|l|l|l|l|l|l|} 
UI4 & 0.643 & 0.72 & 0.701 & 0.687 & 0.528 & 0.632 & 0.687 & 0.639 & 0.697 & 0.889 & 0.687 \\
\hline
\end{tabular}

\begin{tabular}{l|l|l|l|l|l|l|l|l|l|l|l|l|l|} 
UI5 & 0.594 & 0.629 & 0.662 & 0.608 & 0.538 & 0.553 & 0.624 & 0.601 & 0.652 & 0.869 & 0.614 \\
\hline
\end{tabular}

\begin{tabular}{l|l|l|l|l|l|l|l|l|l|l|l|} 
UI6 & 0.588 & 0.621 & 0.668 & 0.602 & 0.517 & 0.579 & 0.655 & 0.643 & 0.689 & 0.852 & 0.646 \\
\hline
\end{tabular}

\begin{tabular}{|l|l|l|l|l|l|l|l|l|l|l|l|}
\hline UI7 & 0.612 & 0.629 & 0.65 & 0.632 & 0.537 & 0.573 & 0.607 & 0.61 & 0.631 & 0.833 & 0.622 \\
\hline
\end{tabular}

\begin{tabular}{l|l|l|l|l|l|l|l|l|l|l|l|l|l|l|} 
US1 & 0.688 & 0.753 & 0.748 & 0.637 & 0.481 & 0.692 & 0.795 & 0.651 & 0.661 & 0.711 & 0.872 \\
\hline
\end{tabular}

\begin{tabular}{l|l|l|l|l|l|l|l|l|l|l|l|} 
US2 & 0.67 & 0.703 & 0.764 & 0.615 & 0.465 & 0.638 & 0.833 & 0.68 & 0.681 & 0.697 & 0.923 \\
\hline
\end{tabular}

\begin{tabular}{l|l|l|l|l|l|l|l|l|l|l|l|} 
US3 & 0.709 & 0.742 & 0.783 & 0.669 & 0.499 & 0.701 & 0.822 & 0.665 & 0.671 & 0.715 & 0.935 \\
\hline
\end{tabular}

\begin{tabular}{l|l|l|l|l|l|l|l|l|l|l|l|l|} 
US4 & 0.643 & 0.689 & 0.768 & 0.639 & 0.465 & 0.657 & 0.801 & 0.715 & 0.683 & 0.694 & 0.904 \\
\hline
\end{tabular}

\begin{tabular}{l|l|l|l|l|l|l|l|l|l|l|l|l|l|} 
US5 & 0.658 & 0.735 & 0.766 & 0.634 & 0.463 & 0.65 & 0.802 & 0.682 & 0.653 & 0.724 & 0.926 \\
\hline
\end{tabular}

\begin{tabular}{|l|l|l|l|l|l|l|l|l|l|l|l|} 
US6 & 0.627 & 0.692 & 0.779 & 0.592 & 0.459 & 0.609 & 0.794 & 0.68 & 0.631 & 0.694 & 0.895 \\
\hline
\end{tabular}

\begin{tabular}{l|l|l|l|l|l|l|l|l|l|l|l|l|} 
US7 & 0.638 & 0.685 & 0.785 & 0.613 & 0.471 & 0.602 & 0.795 & 0.709 & 0.708 & 0.706 & 0.891 \\
\hline
\end{tabular}

\section{APPENDIX B}

Fornell-Larcker of Discriminant Validity

\begin{tabular}{|c|c|c|c|c|c|c|c|c|c|c|c|}
\hline & AOC & D & E & I & IQ & N & PSQ & PUS & SPU & UI & US \\
\hline AOC & 0.851 & & & & & & & & & & \\
\hline D & 0.729 & 0.856 & & & & & & & & & \\
\hline E & 0.71 & 0.759 & 0.861 & & & & & & & & \\
\hline I & 0.77 & 0.733 & 0.694 & 0.849 & & & & & & & \\
\hline IQ & 0.658 & 0.575 & 0.557 & 0.619 & 0.836 & & & & & & \\
\hline N & 0.778 & 0.75 & 0.715 & 0.785 & 0.54 & 0.925 & & & & & \\
\hline PSQ & 0.734 & 0.769 & 0.801 & 0.714 & 0.531 & 0.737 & 0.885 & & & & \\
\hline PUS & 0.649 & 0.698 & 0.833 & 0.639 & 0.501 & 0.66 & 0.711 & 0.903 & & & \\
\hline SPU & 0.705 & 0.688 & 0.819 & 0.722 & 0.556 & 0.698 & 0.75 & 0.816 & 0.881 & & \\
\hline UI & 0.719 & 0.776 & 0.786 & 0.733 & 0.599 & 0.708 & 0.774 & 0.725 & 0.771 & 0.846 & \\
\hline
\end{tabular}

\section{APPENDIX C}

The questionnaire

\begin{tabular}{|l|}
\hline Please answer the following questions by choosing the correct information representing your demographic. \\
\hline 1.Your gender: (Male/Female) \\
\hline 2.Your age: (18 - 24 years/25 - 29 years/ More than 30) \\
\hline 3.Your University Name: (Taibah University/ Taif University/ King Faisal University/ University of Tabuk) \\
\hline 4. Years of experience using computer and internet: (less than 1 year/1 - 3 years/3 - 5 years/5 - 10 years/ More than 10 years) \\
\hline 5. Computer skills: (Low/Good/ Excellent) \\
\hline 6. Internet skills: (Low/Good/ Excellent) \\
\hline
\end{tabular}

B. For the following questions, please rate your perception with regard to your experience in using student portals. (Possible choices: Strongly disagree, Disagree, Neutral, Agree, Strongly Agree)

1. Information Quality (IQ): Refers to the system's output value, as perceived by the users.

I believe that the easy to understand information on the student portal encourages me to use the portal.

I believe the student portal provides accurate information to me as a student.

I believe the information displayed on the student portal is useful to me as a student.

I believe the student portal provides information related to my study needs.

I believe the rich information available on the student portal attracts me to use the portal.

2.Availability of Content (AOC): Refers to the availability of portal content and services which provide to student in their portal.

I believe that if the availability of information content in the student portal meets my needs, it will encourage me to use the portal.

I believe that if online discussions were available in the student portal, that would help me increase my interaction with the portal.

The availability of online course catalogues in the student portal will help me in my study.

I believe that if the student portal provides complete information about the university and the various events, it will attract me to use it.

I believe having contact information such as phone number, fax number, e-mail, and postal address in the portal is helpful to me as a student.

I believe that giving feedback and facilitated question forms in the student portal will increase the interaction with the portal.

I believe that if a help facility was provided in the student portal, that will make the portal more usable.

I believe that if the student portal provides e-mail services to students will help me interact with the portal administration.

I believe that if the student portal contains an e-learning material service, will make my materials easy to access on the portal.

3. Interaction (I): Refers to the interaction between the students, instructors, and the portal services.

I believe that the interaction in the student portal enhances the effectiveness of my academic decisions as a student.

I believe that the interaction in the student portal enhances my productivity in my academic life as a student.

I believe that if the student portal makes online discussion tasks easy to use, will increase my interaction with it.

I believe the interaction allows me to share experiences with other students in the portal.

I believe the instructor can encourage students to increase their interaction with the student portal.

I believe interactive feedback between students and teachers in the student portal will encourage both of them to use it.

4.Navigation (N): Assesses whether a portal includes tools (i.e. navigation menu, internal search facility) and links which facilitate users'navigation.

I believe that if all links are working in my student portal, that will make it more interesting to use

I believe that if the internal search is effective in the student portal, that will help me in mystudy.

I believe that if the internal search is working in the student portal, that will help me to use it.

5. Design (D): Refers to the visual attractiveness of the portal design, the appropriate design of a portal pages and the appropriate use of images, fonts, colors in the portal design.

I believe that if the images in the student portal are interesting, that will increase my satisfaction of the portal

I believe that if there are consistent colors throughout the student portal, that will make the portal more attractive.

I believe that if the student portal menu design is consistent, that will make it more interesting to use.

I believe that if the content text is simple in the student portal, that will make the portal easier to use.

I believe that if the layout of the student portal is very simple, that will make the portal more attractive.

I believe that if the alignment of the header on each page is consistent in the student portal, that will make it more attractive.

I believe that if all pages have proper headings, that will make the portal more interesting to use. 
I believe that if consistent language is used throughout the student portal, that will make the portal easier to use.

I believe that the design makes pleasurable for students to use the student portal services.

6. User Intention (UI): Refers to the behavioral of user intention to use the student portal services.

I believe that if the portal services are worthwhile for students, that will make me use the portal more.

If I get good services, I will use the student portal many times per week.

I plan to use the student portal very often in the future.

If the student portal is enjoyable, $i$ intend to use it in the future.

I intend to use the student portal to conduct university related study tasks.

I predict $i$ will use the student portal in the future.

If I get to use the student portal, $i$ intend to use all of its services.

7. Portal Service Quality (PSQ): Refers to the users evaluation that the service they are receiving from the portal is the service they expect.

I believe the services offered in the student portal should be reliable.

I believe the services offered in the student portal save my time.

I believe the pages should respond fast when I use the portal services.

I believe the student portal should provide sufficient information to achieve my tasks.

I believe the student portal should be flexible to use.

I believe the services offered in the student portal should be comprehensive for all student needs.

I believe the student portal should provide up-to-date information

8. User Satisfaction (US): Refers to student satisfaction about the provided services.

If the quality of information provided through the student portal is good, $i$ will feel satisfied.

If the quality of the student portal system is good, i will feel satisfied.

If the services offered in the student portal meet my needs, that will increase my satisfaction with the portal.

I believe that if the student portal is enjoyable, it will make me satisfied.

If the services offered by the student portal are suited to my needs, that will make me satisfied.

I believe the services offered by the student portal should be easy to use.

I believe that if the process of using the student portal is pleasant, that will make me satisfied.

9. Efficiency (E): Mean users have the ability to organize and perform the actions on the portal in order to achieve their tasks.

I have the ability to download programs and use student portal services.

I believe the student portal services should be easy to use.

I believe that if the information in the student portal is interesting to me, it should be obtained with minimal effort.

I believe that if $i$ find that anyone can use the student portal easily, that will encourage me to use the portal.

I believe that if I can easily navigate the student portal, that will help me to find what i need easily.

I believe the student portal serves its purpose by producing good services.

10 Portal User Support (PUS): The degree to which the usersupport departments are willing to serve the users and provide them with the required services.

I believe the portal loads its pages quickly if user support provides high internet speed.

I believe the user support will help users by providing training in the use of the student portal.

I believe the user support will help users by providing quick responses to their service requests.

I believe the user support will help users by providing correct information.

I believe the user support will help users by providing different browsers where portal pages work.

I believe the user support will help users by providing a help desk.

I believe the user support will help users by providing feedback forms.

I believe the user support will help users by providing orientation in the use of students.

11. Student Portal (SP): Student portal provides services which $m$ atche the study needs from different resources in a single page.

I believe using the student portal will provide me with information that would lead me to produce better research.

I believe using the student portal will make it easier for me to do my assignments and prepare for examinations.

I believe using the student portal will give me access to information that I cannot find elsewhere.

I believe using the student portal will provide me with information that would lead me to produce better research.

\section{REFERENCES}

[1] N. Nasirun, S. M. Noor, Z. M. Nor, H. Ahmat, and Z. Ahmad, "Perceived Web Service Quality for Students' Portal in Higher Learning Institution," in International Proceedings of Economics Development and Research, 2012, vol. 56, pp. 52-56.

[2] H. Al-Dossari, "A Heuristic Based Approach for Usability Evaluation of Academic Portals," International Journal of Computer Science \& Information Technology, vol. 9, no. 3, pp. 15-30, 2017.

[3] M. Mansourvar and N. M. Yasin, "Web portal As A Knowledge Management System In The Universities," World Academy of Science, Engineering and Technology, vol. 70, pp. 968-974, 2010.

[4] N. Thomas-Alvarez and L. Mahdjoubi, "Testing the effectiveness of a web-based portal system for the building control sector," Automation in Construction, vol. 29, pp. 196-204, Jan. 2013, https://doi.org/10.1016/ j.autcon.2012.02.018.

[5] A. Altameem, "What drives successful e-learning? An empirical investigation of the key technical issues in Saudi Arabian universities,"
Journal of Theoretical and Applied Information Technology, vol. 53, no. 1, pp. 63-70, 2013.

[6] S. M. Al-Turki, "Assessment of information technology awareness and usage in higher education in Saudi Arabia: sample study in Jazan and King Faisal University KSA," International Journal of Advanced Research in IT and Engineering, vol. 3, no. 9, pp. 1-17, 2014.

[7] M. Althonayan and A. Papazafeiropoulou, "Evaluating the Performance of ERP Systems in Saudi Arabian Higher Education: A Stakeholders' Perspective," in 2nd International Conference on Information Management and Evaluation, London, UK, Apr. 2011, pp. 473-482.

[8] K. A. Al-Busaidi, "The payoff of corporate portal usage in an academic institution," Campus-Wide Information Systems, vol. 29, no. 5, pp. 368379, Jan. 2012, https://doi.org/10.1108/10650741211275125.

[9] H. Gul, S. Z. Iqbal, and M. Saqib, "Usability Evaluation of an Educational Website in Saudi Arabia," VAWKUM Transactions on Computer Sciences, vol. 3, no. 1, pp. 84-92, Dec. 2015, https://doi.org/ 10.21015/vtcs.v8i2.382.

[10] M. Benaida, A. Namoun, and A. Taleb, "Evaluation of the Impact of Usability in Arabic University Websites: Comparison between Saudi 
Arabia and the UK," International Journal of Advanced Computer Science and Applications, vol. 9, no. 8, pp. 365-375, 2018.

[11] K. Al-Omar, "Evaluating the Internal and External Usability Attributes of E-Learning Websites in Saudi Arabia," Advanced Computing: An International Journal, vol. 8, no. 3/4, pp. 1-12, Jul. 2017.

[12] NaifJabli, H. Alghamdi, and F. Demir, "The Usability Of King Khalid University Website: Assessing Effectiveness, Efficiency, And Satisfaction," International Journal of Arts Humanities and Social Sciences, vol. 3, no. 7, pp. 10-16, 2018.

[13] Y. F. Hassan, "Cellular Automata For Adaptive Web Portal Structure In Egyptian Universities," International Journal of Engineering Sciences \& Emerging Technologies, vol. 6, no. 2, pp. 133-141, 2013.

[14] S. Bahaj, K. Aljaaidi, and T. Ahmed, "Using TAM model to empirically examine students' attitudes towards e-services in college of business administration," Management Science Letters, vol. 9, no. 5, pp. 651-660, 2019.

[15] M. Al Harbi, "Faculty Attitudes Toward and Motivation for Virtual Learning Environments (VLE) for Language Studies: A Cross-National Study in Saudi Arabian Universities," Journal of Psychology and Behavioral Science, vol. 4, no. 2, pp. 100-114, 2016.

[16] A. Ahmed and S. Al-Reyaee, "Knowledge and Use of Electronic Information Resources by Medical Students at Al-Jouf University in Saudi Arabia," Library Philosophy and Practice, vol. 1524, Mar. 2017.

[17] A. Alhabeeb and J. Rowley, "Critical success factors for eLearning in Saudi Arabian universities," International Journal of Educational Management, vol. 31, no. 2, pp. 131-147, Jan. 2017.

[18] M. Alshamari, "Usability Factors Assessment in Health Information System," Intelligent Information Management, vol. 8, no. 6, pp. 170180, Nov. 2016, https://doi.org/10.4236/iim.2016.86012.

[19] A. M. Elsayed, "Web content strategy in higher education institutions: The case of King Abdulaziz University," Information Development, vol. 33, no. 5, pp. 479-494, Nov. 2017, https://doi.org/10.1177/ 0266666916671387.

[20] N. J. H. Al-Mashaqba, "Use of Blackboard Collaborate at Qassim University: Evaluating Teachers' Perceptions," Sino-US English Teaching, vol. 14, no. 2, pp. 76-85, 2017, https://doi.org/10.17265/15398072/2017.02.002

[21] S. M. Almahamid, A. F. Tweiqat, and M. S. Almanaseer, "University website quality characteristics and success: lecturers' perspective," International Journal of Business Information Systems, vol. 22, no. 1, pp. 41-61, Jan. 2016, https://doi.org/10.1504/IJBIS.2016.075717.

[22] L. Alkahtani, "The Attitudes of Princess Nora University Students Towards Using Electronic Information Resources of the Library," Proceedings from the Document Academy, vol. 3, no. 2, Dec. 2016, Art. no. 8, https://doi.org/10.35492/docam/3/2/8.

[23] A. Badwelan, S. Drew, and A. A. Bahaddad, "Towards Acceptance MLearning Approach in Higher Education in Saudi Arabia," International Journal of Business and Managemen, vol. 11, no. 8, pp. 12-30, 2016.

[24] S S. Alkhalaf, "Evaluating m-learning in Saudi Arabian higher education: a case study," arXiv:1510.03189 [cs], Oct. 2015, [Online]. Available: http://arxiv.org/abs/1510.03189.

[25] M. Y. Wu, H. P. Chou, Y. C. Weng, and Y. H. Huang, "TAM-2 based study of website user behavior-using web 2.0 websites as an example," WSEAS Transactions on Business and Economics, vol. 8, no. 4, pp. 133$151,2011$.

[26] A. Benlian, "Web Personalization Cues and Their Differential Effects on User Assessments of Website Value," Journal of Management Information Systems, vol. 32, no. 1, pp. 225-260, Jan. 2015, https://doi.org/10.1080/07421222.2015.1029394.

[27] V. Venkatesh, M. G. Morris, G. B. Davis, and F. D. Davis, "User acceptance of information technology: Toward a unified view," MIS Quarterly: Management Information Systems, vol. 27, no. 3, pp. 425478, Sep. 2003, https://doi.org/10.2307/30036540.

[28] Y.-H. Chen and I. Chengalur-Smith, "Factors influencing students' use of a library Web portal: Applying course-integrated information literacy instruction as an intervention," The Internet and Higher Education, vol. 26, pp. 42-55, Jul. 2015, https://doi.org/10.1016/j.iheduc.2015.04.005.
[29] W. H. DeLone and E. R. McLean, "Information Systems Success: The Quest for the Dependent Variable," Information Systems Research, vol. 3, no. 1, pp. 60-95, Mar. 1992, https://doi.org/10.1287/isre.3.1.60.

[30] P. Longinidis and K. Gotzamani, "ERP user satisfaction issues: insights from a Greek industrial giant," Industrial Management \& Data Systems, vol. 109, no. 5, pp. 628-645, Jan. 2009, https://doi.org/10.1108/ 02635570910957623.

[31] P. T. Kotler and K. L. Keller, Marketing Management, 14th edition. Upper Saddle River, NJ, USA: Pearson, 2011.

[32] A. Tella and M. T. Bashorun, "Undergraduate Students' Satisfaction with the Use of Web Portals," International Journal of Web Portals, vol. 4, no. 2, pp. 56-73, Apr. 2012, https://doi.org/10.4018/jwp.2012040104.

[33] V. McKinney, K. Yoon, and F. "Mariam" Zahedi, "The Measurement of Web-Customer Satisfaction: An Expectation and Disconfirmation Approach," Information Systems Research, vol. 13, no. 3, pp. 296-315, Sep. 2002, https://doi.org/10.1287/isre.13.3.296.76.

[34] L. C. Schaupp, "Web Site Success: Antecedents of Web Site Satisfaction and Re-use," Journal of Internet Commerce, vol. 9, no. 1, pp. 42-64, Jun. 2010, https://doi.org/10.1080/15332861.2010.487414.

[35] S. Thuseethan, S. Achchuthan, and S. Kuhanesan, "Usability Evaluation of Learning Management Systems in Sri Lankan Universities," arXiv:1412.0197 [cs], Feb. 2015, [Online]. Available: http://arxiv.org/ $\mathrm{abs} / 1412.0197$.

[36] E. Sung and R. E. Mayer, "Affective impact of navigational and signaling aids to e-learning," Computers in Human Behavior, vol. 28, no. 2, pp. 473-483, Mar. 2012, https://doi.org/10.1016/j.chb.2011. 10.019 .

[37] M. Bajec, "Educational Portals: A Way to Get an Integrated, UserCentric University Information System," in Web Portals: The New Gateways to Internet Information and Services, Melbourne, Australia: Idea Group, 2005, pp. 252-269.

[38] A. M. Shaltoni, H. Khraim, A. Abuhamad, and M. Amer, "Exploring students' satisfaction with universities' portals in developing countries: A cultural perspective," The International Journal of Information and Learning Technology, vol. 32, no. 2, pp. 82-93, Jan. 2015, https://doi.org/10.1108/IJILT-12-2012-0042.

[39] S. Petter, W. DeLone, and E. McLean, "Measuring information systems success: models, dimensions, measures, and interrelationships," European Journal of Information Systems, vol. 17, no. 3, pp. 236-263, Jun. 2008, https://doi.org/10.1057/ejis.2008.15.

[40] A. H. R. Zaied, "An Integrated Success Model for Evaluating Information System in Public Sectors," Journal of Emerging Trends in Computing and Information Sciences, vol. 3, no. 6, pp. 814-825, 2012.

[41] S. Lee, "Academic Library E-Service User Motivation: A Korean Case Study," Libri, vol. 62, no. 3, pp. 233-247, Sep. 2012, https://doi.org/ 10.1515/libri-2012-0019.

[42] X. Zhang and V. R. Prybutok, "A consumer perspective of E-service quality," IEEE Transactions on Engineering Management, vol. 52, no. 4, pp. 461-477, Nov. 2005, https://doi.org/10.1109/TEM.2005.856568.

[43] S. Vairamuthu and S. M. Anouncia, "Reconnoitering Students' Satisfaction of an Online Based Assessment System to Improve Usability using PSO: An Examination into a Problem Solving and Programming Course," Engineering, Technology \& Applied Science Research, vol. 6, no. 5, pp. 1207-1211, Oct. 2016, https://doi.org/ 10.48084/etasr. 800 .

[44] K. P. Asiimwe, D. Machuve, and M. A. Dida, "Usability Testing of a Web Portal for Ornamental Plants and Flowers in Arusha, Tanzania," Engineering, Technology \& Applied Science Research, vol. 10, no. 3, pp. 5627-5631, Jun. 2020, https://doi.org/10.48084/etasr.3412.

[45] C. Liu and K. P. Arnett, "Exploring the factors associated with Web site success in the context of electronic commerce," Information \& Management, vol. 38, no. 1, pp. 23-33, Oct. 2000, https://doi.org/ 10.1016/S0378-7206(00)00049-5.

[46] L. Cobus, V. F. Dent, and A. Ondrusek, "How Twenty-Eight Users Helped Redesign an Academic Library Web Site: A Usability Study," Reference \& User Services Quarterly, vol. 44, no. 3, pp. 232-246, 2005. 
[47] A. Aggarwal, Web-Based Learning and Teaching Technologies: Opportunities and Challenges: Opportunities and Challenges. London, UK: Idea Group, 1999.

[48] J. M. Pearson and A. M. Pearson, "An Exploratory Study into Determining the Relative Importance of Key Criteria in Web Usability: A Multi-Criteria Approach," Journal of Computer Information Systems, vol. 48, no. 4, pp. 115-127, Jun. 2008, https://doi.org/10.1080/ 08874417.2008.11646041

[49] P. N. Sindhuja and S. G. Dastidar, "Impact of the Factors Influencing Website Usability on User Satisfaction," IUP Journal of Management Research, vol. 8, no. 12, pp. 54-66, Dec. 2009.

[50] D. U. Bolliger, "Key Factors for Determining Student Satisfaction in Online Courses," International Journal on E-Learning, vol. 3, no. 1, pp. 61-67, 2004.

[51] R. Aziz and B. Shahzad, "Factors for Measurement of ITES Quality for Higher Education Institutions in Saudi Arabia," Global Journal of Computer Science and Technology, vol. 15, no. 3, May 2015.

[52] A. Bandura, Social foundations of thought and action: A social cognitive theory. Englewood Cliffs, NJ, USA: Prentice-Hall, 1986.

[53] A. Bandura, Self-efficacy: the exercise of control. New York, NY, USA: W.H. Freeman and Company, 1997.

[54] W. Liu et al., "Internet-Enabled User Interfaces for Distance Learning," International Journal of Technology and Human Interaction, vol. 5, no. 1, pp. 51-77, Jan. 2009, https://doi.org/10.4018/jthi.2009010105.

[55] P. R. Warshaw and F. D. Davis, "Disentangling behavioral intention and behavioral expectation," Journal of Experimental Social Psychology, vol. 21, no. 3, pp. 213-228, May 1985, https://doi.org/10.1016/00221031(85)90017-4.

[56] M. A. Mahmood, L. Hall, and D. L. Swanberg, "Factors Affecting Information Technology Usage: A Meta-Analysis of the Empirical Literature," Journal of Organizational Computing and Electronic Commerce, vol. 11, no. 2, pp. 107-130, Jun. 2001, https://doi.org/ 10.1207/S15327744JOCE1102 02.

[57] V. Venkatesh and F. D. Davis, "A Theoretical Extension of the Technology Acceptance Model: Four Longitudinal Field Studies," Management Science, vol. 46, no. 2, pp. 186-204, Feb. 2000, https://doi.org/10.1287/mnsc.46.2.186.11926.

[58] M. Turner, B. Kitchenham, P. Brereton, S. Charters, and D. Budgen, "Does the technology acceptance model predict actual use? A systematic literature review," Information and Software Technology, vol. 52, no. 5, pp. 463-479, May 2010, https://doi.org/10.1016/j.infsof.2009.11.005.

[59] Y. Haliso, "Factors Affecting Information and Communication Technologies (ICTs) Use by Academic Librarians in Southwestern Nigeria," Library Philosophy and Practice (e-journal), Apr. 2011, [Online]. Available: https://digitalcommons.unl.edu/libphilprac/571.

[60] F. Alturise and B. Alojaiman, "Benefits and challenges of using ICT in Saudi Arabia universities: A literature review," in International Conference on Advanced in Computing, Engineering and Learning Technologies, 2013, vol. 2.

[61] M. Verbree, E. Horlings, P. Groenewegen, I. Van der Weijden, and P. van den Besselaar, "Organizational factors influencing scholarly performance: a multivariate study of biomedical research groups," Scientometrics, vol. 102, no. 1, pp. 25-49, Jan. 2015, https://doi.org/ 10.1007/s11192-014-1437-x.

[62] U. Sekaran and R. Bougie, Research Methods For Business: A Skill Building Approach, 7th edition. Chichester, WS, UK: Wiley, 2016.

[63] R. G. Netemeyer, W. O. Bearden, and S. Sharma, Scaling Procedures: Issues and Applications, 1 st edition. Thousand Oaks, CA, USA: SAGE, 2003.

[64] D. F. Polit and C. T. Beck, "The content validity index: Are you sure you know what's being reported? critique and recommendations," Research in Nursing \& Health, vol. 29, no. 5, pp. 489-497, 2006, https://doi.org/10.1002/nur.20147.

[65] M.-C. Boudreau, D. Gefen, and D. W. Straub, "Validation in Information Systems Research: A State-of-the-Art Assessment," MIS Quarterly, vol. 25, no. 1, pp. 1-16, 2001, https://doi.org/10.2307/ 3250956.
[66] V. Zamanzadeh, A. Ghahramanian, M. Rassouli, A. Abbaszadeh, H. Alavi-Majd, and A.-R. Nikanfar, "Design and Implementation Content Validity Study: Development of an instrument for measuring PatientCentered Communication," Journal of Caring Sciences, vol. 4, no. 2, pp. 165-178, Jun. 2015, https://doi.org/10.15171/jcs.2015.017.

[67] J. Hair, G. T. M. Hult, C. M. Ringle, and M. Sarstedt, A Primer on Partial Least Squares Structural Equation Modeling, 2nd edition. Los Angeles, CA, USA: SAGE, 2016.

[68] J. F. Hair Jr, M. Sarstedt, L. Hopkins, and V. G. Kuppelwieser, "Partial least squares structural equation modeling (PLS-SEM): An emerging tool in business research," European Business Review, vol. 26, no. 2, pp. 106-121, Jan. 2014, https://doi.org/10.1108/EBR-10-2013-0128.

[69] S. B. MacKenzie, P. M. Podsakoff, and N. P. Podsakoff, "Construct Measurement and Validation Procedures in MIS and Behavioral Research: Integrating New and Existing Techniques," MIS Quarterly, vol. 35, no. 2, pp. 293-334, 2011, https://doi.org/10.2307/23044045.

[70] M. Tenenhaus, V. E. Vinzi, Y.-M. Chatelin, and C. Lauro, "PLS path modeling," Computational Statistics \& Data Analysis, vol. 48, no. 1, pp. 159-205, Jan. 2005, https://doi.org/10.1016/j.csda.2004.03.005.

[71] J. Henseler and M. Sarstedt, "Goodness-of-fit indices for partial least squares path modeling," Computational Statistics, vol. 28, no. 2, pp. 565-580, Apr. 2013, https://doi.org/10.1007/s00180-012-0317-1.

[72] M. Wetzels, G. Odekerken-Schroder, and C. van Oppen, "Using PLS Path Modeling for Assessing Hierarchical Construct Models: Guidelines and Empirical Illustration," MIS Quarterly, vol. 33, no. 1, pp. 177-195, 2009, https://doi.org/10.2307/20650284.

[73] M. Zviran, C. Glezer, and I. Avni, "User satisfaction from commercial web sites: The effect of design and use," Information \& Management, vol. 43, no. 2, pp. 157-178, Mar. 2006, https://doi.org/10.1016/ j.im.2005.04.002.

[74] "Learner-Centered Psychological Principles: Guidelines for School Redesign and Reform," American Psychological Association, Washington, DC, USA, Jan. 1993.

[75] S. M. Abdulhamid and I. Idris, "Design Evaluation of Some Nigerian University Portals: A Programmer's Point of View," arXiv:1402.1241 [cs], Feb. 2014, [Online]. Available: http://arxiv.org/abs/1402.1241.

[76] K. M. Alsharif, "Towards quality teacher education: productive pedagogies as a framework for Saudi pre-service teachers' training in Mathematics education," Ph.D. dissertation, Curtin University, Perth, Australia, 2011

[77] F. O. Oliha, "Web Portal Usability among Nigerian University Students: A Case Study of University Of Benin, Nigeria," Nigerian Journal of Technology, vol. 33, no. 2, pp. 199-206, Apr. 2014, https://doi.org/ 10.4314/njt.v33i2.9.

[78] J. C. Roca, C.-M. Chiu, and F. J. Martinez, "Understanding e-learning continuance intention: An extension of the Technology Acceptance Model," International Journal of Human-Computer Studies, vol. 64, no. 8, pp. 683-696, Aug. 2006, https://doi.org/10.1016/j.ijhcs.2006.01.003. 